\title{
Tourism Demand Modelling and Forecasting A Review of Recent Research
}

\author{
Haiyan Song ${ }^{1}$ \\ School of Hotel and Tourism Management \\ The Hong Kong Polytechnic University \\ Hung Hom, Kowloon \\ Hong Kong SAR \\ Gang Li \\ School of Management \\ University of Surrey \\ Guildford GU2 7XH, UK
}

\begin{abstract}
This paper reviews the published studies on tourism demand modelling and forecasting since 2000. One of the key findings of this review is that the methods used in analysing and forecasting the demand for tourism have been more diverse than those identified by other review articles. In addition to the most popular time series and econometric models, a number of new techniques have emerged in the literature. However, as far as the forecasting accuracy is concerned, the study shows that there is no single model that consistently outperforms other models in all situations. Furthermore, this study identifies some new research directions, which include improving the forecasting accuracy through forecast combination; integrating both qualitative and quantitative forecasting approaches, tourism cycles and seasonality analysis, events' impact assessment and risk forecasting.
\end{abstract}

Key words: tourism demand; modelling; forecasting

\section{Introduction}

Along with the phenomenal growth in demand for tourism in the world over the past two decades is a growing interest in tourism research. Twenty years ago there were only a handful of academic journals that published tourism related research. Now there are more than 70 journals that serve a thriving research community covering more than 3,000 tertiary institutions across five continents. Being one of the important areas in tourism research, tourism demand modelling and forecasting has attracted much attention of both academics and practitioners. According to a comprehensive review by Li et al (2005),

\footnotetext{
${ }^{1}$ Corresponding author (hmsong@polyu.edu.hk). The authors acknowledge the financial support of the Hong Kong University Grants Council's Competitive Earmarked Research Grant - B-Q976.
} 
420 studies on this topic were published during the period 1960-2002. The majority of these studies focus on the application of different techniques, both qualitative and quantitative, to model and forecast the demand for tourism in various destinations. These studies also attempted to establish forecasting principles that could be used to guide the practitioners in selecting forecasting techniques. However, this effort has not been successful. As Witt and Song (2000) and Li et al (2005) concluded, the performance of the forecasting models varies according to the data frequencies used in the model estimation, the destination-origin country/region pairs under consideration and the length of the forecasting horizons concerned. There has not been a panacea for tourism demand forecasting.

A number of review articles on tourism demand forecasting have been published over the last decade and these include Crouch (1994), Li et al (2005), Lim (1997a, 1997b and 1999) and Witt and Witt (1995). These reviews cover the studies published mostly during the period 1960-2000. Although a few studies published between 2000 and 2004 are included in the latest review of Li et al (2005), the focus of that review was on the econometric approach only. This paper does not attempt to duplicate the efforts made by previous researchers in reviewing the pre-2000 publications and only concentrates on the most recent publications since 2000. The current review provides a full account of all methods used in tourism demand modelling and forecasting, including time series models, the econometric approach as well as some emerging new statistical and non-statistical methods. The main objective is, therefore, to investigate whether there are any new trends/issues emerging recently in tourism forecasting literature and to suggest new directions for future research based on the new trends and issues identified.

The authors conducted a search on various databases such as the social science citation index (SSCI), Google Scholar, and citations from published articles. One hundred and twenty one journal papers on tourism demand modelling and forecasting published since 2000 are identified. A full list of these articles is provided in Table 1 . The review is therefore based on these 121 studies and the emphasis is placed on the following issues: the latest methodological developments, forecast competition, combination and integration, tourism cycles, turning points, directional changes and seasonality analysis, events' impact analysis and risk forecasting in addition to some general observations. 
Table 1

\section{Summary of Post-2000 Tourism Demand Modelling and Forecasting Studies}

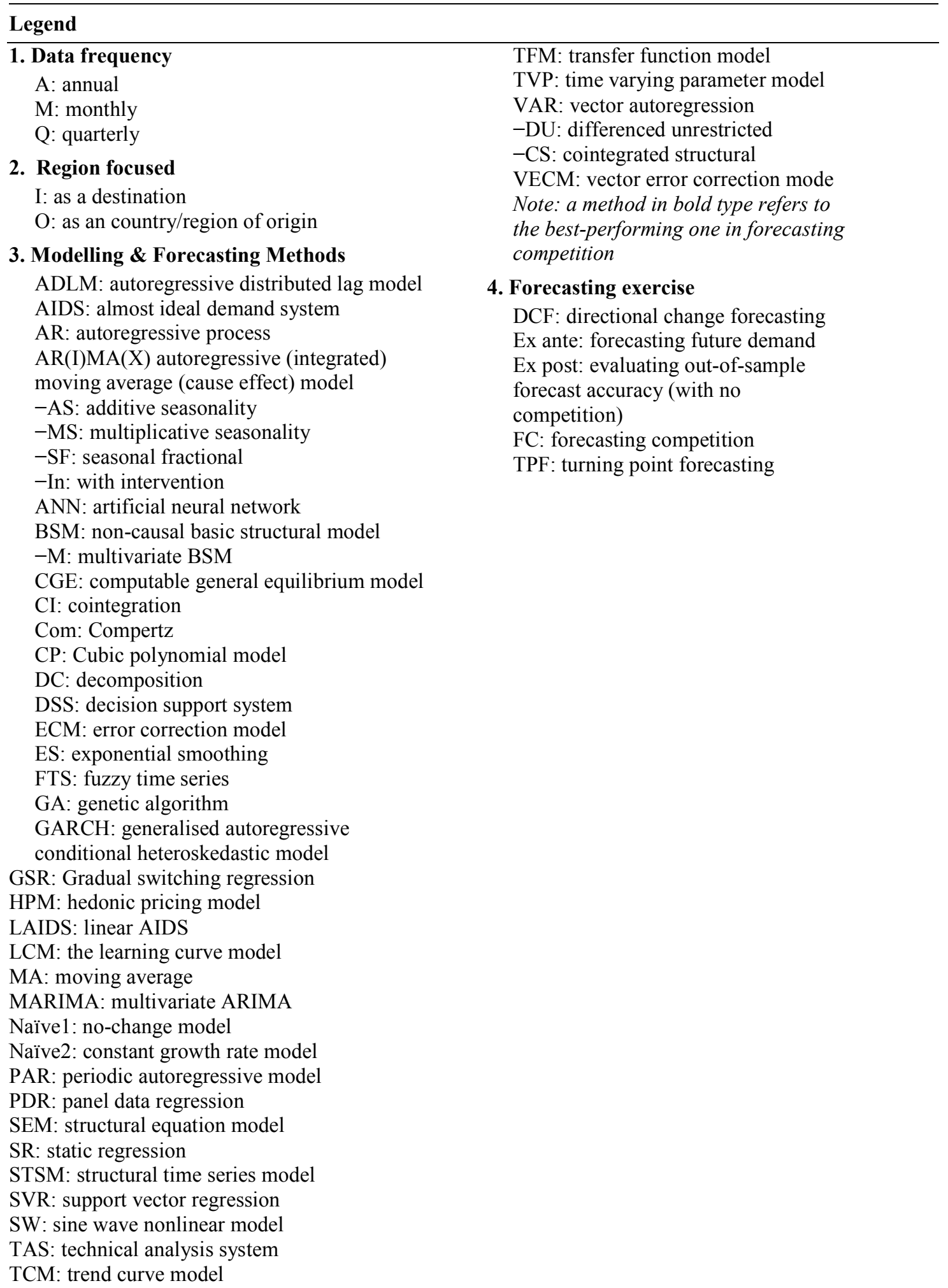




\begin{tabular}{|c|c|c|c|c|c|}
\hline Study & $\begin{array}{l}\text { 1. Data } \\
\text { Frequency }\end{array}$ & $\begin{array}{l}\text { 2. Region } \\
\text { Focused }\end{array}$ & $\begin{array}{l}\text { 3. Modelling \& } \\
\text { Forecasting Methods }\end{array}$ & $\begin{array}{c}\text { 4.Forecasting } \\
\text { exercise }\end{array}$ & 5. Research theme \\
\hline $\begin{array}{l}\text { Aguiló et al } \\
(2005)\end{array}$ & $\mathrm{A}$ & $\begin{array}{l}\text { Balearic } \\
\text { Islands (I) }\end{array}$ & $\begin{array}{l}\text { Information transmission } \\
\text { model }\end{array}$ & No & Price effect of a tourist tax \\
\hline Akal (2004) & A & Turkey (I) & ARMAX SR & $\begin{array}{l}\text { Exante } \\
\text { FC }\end{array}$ & $\begin{array}{l}\text { Forecasting tourism } \\
\text { revenues by ARMAX }\end{array}$ \\
\hline Algieri (2006) & M & Russia (I) & $\mathrm{CI}$ & & $\begin{array}{l}\text { Cointegration analysis of } \\
\text { tourism demand }\end{array}$ \\
\hline Alleyne (2006) & Q & Jamaica (I) & SARIMA PAR & $\mathrm{FC}$ & $\begin{array}{l}\text { Pre-testing of seasonal unite } \\
\text { root and forecast accuracy }\end{array}$ \\
\hline Au \& Law (2000) & A & $\begin{array}{l}\text { Hong Kong } \\
\text { (I) }\end{array}$ & Rough sets & Expost & $\begin{array}{l}\text { Using rough sets to forecast } \\
\text { sightseeing expenditure }\end{array}$ \\
\hline Au \& Law (2002) & A & $\begin{array}{l}\text { Hong Kong } \\
\text { (I) }\end{array}$ & Rough sets & Expost & $\begin{array}{l}\text { Applying rough sets to } \\
\text { forecast dinning expenditure }\end{array}$ \\
\hline Bicak et al (2005) & A & $\begin{array}{l}\text { North Cyprus } \\
\text { (I) }\end{array}$ & SR Trend-fitting model & Ex ante & $\begin{array}{l}\text { Forecasting future tourism } \\
\text { demand }\end{array}$ \\
\hline Blake et al (2006) & Q & Scotland (I) & STSM CGE & Exante & $\begin{array}{l}\text { Integrating econometric } \\
\text { forecasting and CGE models }\end{array}$ \\
\hline $\begin{array}{l}\text { Burger et al } \\
(2001)\end{array}$ & M & $\begin{array}{l}\text { South Africa } \\
\text { (I) }\end{array}$ & $\begin{array}{l}\text { ANN Naïve } 1 \text { MA ES } \\
\text { GA ARIMA SR }\end{array}$ & $\mathrm{FC}$ & Forecast accuracy comparison \\
\hline Chan et al (2005) & M & Australia (I) & ARMA-GARCH & No & $\begin{array}{l}\text { Modelling multivariate tourism } \\
\text { demand and volatility }\end{array}$ \\
\hline $\begin{array}{l}\text { Chen \& Wang } \\
(2007)\end{array}$ & Q & China (I) & $\begin{array}{l}\text { GA-SVR ANN } \\
\text { SARIMA }\end{array}$ & $\mathrm{FC}$ & Forecasting with GA-SVR \\
\hline Cho (2001) & Q & $\begin{array}{l}\text { Hong Kong } \\
\text { (I) }\end{array}$ & ARIMAX ARIMA ES & $\mathrm{FC}$ & $\begin{array}{l}\text { Leading economic indicators } \\
\text { and forecasting accuracy }\end{array}$ \\
\hline Cho (2003) & M & $\begin{array}{l}\text { Hong Kong } \\
\text { (I) }\end{array}$ & ANN ES ARIMA & $\mathrm{FC}$ & Forecast accuracy comparison \\
\hline Chu (2004) & M & Singapore (I) & Naïve 1, 2 SR SW CP & $\mathrm{FC}$ & $\begin{array}{l}\text { Forecasting with cubic } \\
\text { polynomial model }\end{array}$ \\
\hline Coshall (2000) & Q & UK to USA & Spectral analysis & No & $\begin{array}{l}\text { Spectral analysis of tourism } \\
\text { demand }\end{array}$ \\
\hline Coshall (2005) & Q & UK $(\mathrm{O})$ & $\begin{array}{c}\text { ARIMA-MS ARIMA- } \\
\text { AS }\end{array}$ & $\mathrm{FC}$ & Model selection strategy \\
\hline $\begin{array}{l}\text { Croes \& Vanegas } \\
(2005)\end{array}$ & A & Aruba (I) & $\begin{array}{c}\text { Linear \& log-linear } \\
\text { ADLM }\end{array}$ & No & $\begin{array}{l}\text { Econometric analysis of } \\
\text { tourism demand }\end{array}$ \\
\hline $\begin{array}{l}\text { Daniel \& Ramos } \\
(2002)\end{array}$ & A & Portugal (I) & CI ECM & No & $\begin{array}{l}\text { Econometric analysis of } \\
\text { tourism demand }\end{array}$ \\
\hline $\begin{array}{l}\text { De Mello \& } \\
\text { Fortuna (2005) }\end{array}$ & A & UK (O) & $\begin{array}{l}\text { Dynamic LAIDS Static } \\
\text { LAIDS, ADLM }\end{array}$ & $\mathrm{FC}$ & $\begin{array}{l}\text { Testing alternative dynamic } \\
\text { demand systems }\end{array}$ \\
\hline $\begin{array}{l}\text { De Mello \& Nell } \\
(2005)\end{array}$ & $\mathrm{A}$ & UK $(\mathrm{O})$ & $\begin{array}{l}\text { LAIDS VAR VAR-DU } \\
\text { VAR-CS }\end{array}$ & $\mathrm{FC}$ & $\begin{array}{l}\text { Forecast accuracy comparison } \\
\text { focusing on VAR-CS }\end{array}$ \\
\hline $\begin{array}{l}\text { De Mello et al } \\
(2002)\end{array}$ & A & UK $(\mathrm{O})$ & LAIDS & expost & $\begin{array}{l}\text { Demand modelling with } \\
\text { AIDS }\end{array}$ \\
\hline Divisekera (2003) & $\begin{array}{l}\text { Not } \\
\text { reported }\end{array}$ & $\begin{array}{l}\text { Japan US New } \\
\text { Zealand UK }(\mathrm{O})\end{array}$ & LAIDS & No & $\begin{array}{l}\text { Demand modelling with } \\
\text { AIDS }\end{array}$ \\
\hline Dritsakis (2004) & A & Greece (I) & CI VECM & No & $\begin{array}{l}\text { Cointegration analysis of } \\
\text { tourism demand }\end{array}$ \\
\hline $\begin{array}{l}\text { Dritsakis \& Atha- } \\
\text { nasiadis (2000) }\end{array}$ & A & Greece (I) & ADLM & No & $\begin{array}{l}\text { Econometric analysis of } \\
\text { tourism demand }\end{array}$ \\
\hline $\begin{array}{l}\text { Du Preez \& Witt } \\
\text { (2003) }\end{array}$ & M & $\begin{array}{l}\text { Seychelles } \\
\text { (I) }\end{array}$ & SARIMA BSM BSM-M & $\mathrm{FC}$ & $\begin{array}{l}\text { Univariate vs. multivariate } \\
\text { forecasting }\end{array}$ \\
\hline $\begin{array}{l}\text { Durbarry \& } \\
\text { Sinclair (2003) }\end{array}$ & A & France $(\mathrm{O})$ & EC-LAIDS & No & $\begin{array}{l}\text { Market share analysis using } \\
\text { dynamic AIDS }\end{array}$ \\
\hline $\begin{array}{l}\text { Eugenio-Martin et } \\
\text { al (2005) }\end{array}$ & Q & Scotland (I) & STSM & Expost & Crisis impact analysis \\
\hline
\end{tabular}




\begin{tabular}{|c|c|c|c|c|c|}
\hline $\begin{array}{l}\text { Gallet \& Braun } \\
(2001)\end{array}$ & A & $\operatorname{USA}(\mathrm{O})$ & GSR & No & $\begin{array}{l}\text { Demand modelling using } \\
\text { GSR procedure }\end{array}$ \\
\hline $\begin{array}{l}\text { Garín-Muñoz \& } \\
\text { Amaral (2000) }\end{array}$ & A & Spain (I) & Static/dynamic PDR & No & $\begin{array}{l}\text { Econometric analysis using } \\
\text { panel data techniques }\end{array}$ \\
\hline Gil-Alana (2005) & M & USA (I) & ARIMA-SF SARIMA & $\mathrm{FC}$ & $\begin{array}{l}\text { Modelling demand using } \\
\text { seasonal long-memory process }\end{array}$ \\
\hline $\begin{array}{l}\text { Gil-Alana et al } \\
\text { (2004) }\end{array}$ & Q & Spain (I) & ARIMA-SF & No & $\begin{array}{l}\text { Modelling demand using } \\
\text { seasonal long-memory process }\end{array}$ \\
\hline $\begin{array}{l}\text { Goh \& Law } \\
(2002)\end{array}$ & M & $\begin{array}{l}\text { Hong Kong } \\
\text { (I) }\end{array}$ & $\begin{array}{l}\text { SARIMA-In SARIMA } \\
\text { Naïve1,2 MA ES ARIMA }\end{array}$ & $\mathrm{FC}$ & $\begin{array}{l}\text { Modelling demand using } \\
\text { SARIMA with intervention }\end{array}$ \\
\hline $\begin{array}{l}\text { Goh \& Law } \\
(2003)\end{array}$ & A & $\begin{array}{l}\text { Hong Kong } \\
\text { (I) }\end{array}$ & Rough sets & Expost & $\begin{array}{l}\text { Rough sets theory and demand } \\
\text { analysis }\end{array}$ \\
\hline $\begin{array}{l}\text { Gouveia \& } \\
\text { Rodrigues (2005) }\end{array}$ & M & Portugal (I) & Non-parametric method & No & $\begin{array}{l}\text { Dating and synchronising } \\
\text { tourism cycles }\end{array}$ \\
\hline Greenidge (2001) & A & Barbados (I) & STSM BSM & $\mathrm{FC}$ & $\begin{array}{l}\text { Forecasting with structural } \\
\text { time series models }\end{array}$ \\
\hline $\begin{array}{l}\text { Gustavsson \& } \\
\text { Nordstrom (2001) }\end{array}$ & M & Sweden (I) & Vector-ARMA ARMA & $\mathrm{FC}$ & $\begin{array}{l}\text { Vector ARMA modelling } \\
\text { and forecasting }\end{array}$ \\
\hline Han et al (2006) & Q & US to Europe & $\begin{array}{l}\text { LAIDS with different } \\
\text { price indices }\end{array}$ & $\mathrm{FC}$ & $\begin{array}{l}\text { Demand modelling with } \\
\text { AIDS }\end{array}$ \\
\hline $\begin{array}{l}\text { Hernández-López } \\
\text { (2004) }\end{array}$ & $\begin{array}{l}\text { Survey } \\
\text { data }\end{array}$ & Tenerife (I) & genetic algorithm & Expost & $\begin{array}{l}\text { Tourists' characteristics and } \\
\text { demand: genetic algorithm }\end{array}$ \\
\hline $\begin{array}{l}\text { Hernández-López } \\
\text { et al (2007) }\end{array}$ & $\begin{array}{l}\text { Survey } \\
\text { data }\end{array}$ & Tenerife (I) & $\begin{array}{l}\text { genetic algorithm with } \\
\text { transition matrix }\end{array}$ & Expost & $\begin{array}{l}\text { Tourists' characteristics and } \\
\text { demand: genetic algorithm }\end{array}$ \\
\hline Hu et al (2004) & Daily & $\begin{array}{l}\text { a US- } \\
\text { restaurant }\end{array}$ & Naïve1,2 MA ES SR & $\mathrm{FC}$ & $\begin{array}{l}\text { Forecasting Casino } \\
\text { restaurant's daily customers }\end{array}$ \\
\hline $\begin{array}{l}\text { Huang \& Min } \\
\text { (2002) }\end{array}$ & M & Taiwan (I) & SARIMA & Expost & $\begin{array}{l}\text { Impact of earthquake on } \\
\text { tourism }\end{array}$ \\
\hline Ismail et al (2000) & A & $\begin{array}{l}\text { Japan to } \\
\text { Guam }\end{array}$ & ADLM & Expost & $\begin{array}{l}\text { Econometric analysis of } \\
\text { tourism demand }\end{array}$ \\
\hline $\begin{array}{l}\text { Kim \& Moosa } \\
(2001)\end{array}$ & M & Australia (I) & $\begin{array}{c}\text { AR SARIMA ARIMA } \\
\text { BSM }\end{array}$ & $\mathrm{FC}$ & $\begin{array}{l}\text { Deterministic vs. stochastic } \\
\text { seasonality \& forecasts }\end{array}$ \\
\hline $\begin{array}{l}\text { Kim \& Moosa } \\
(2005)\end{array}$ & M & Australia (I) & SARIMA AR BSM & $\mathrm{FC}$ & $\begin{array}{l}\text { Direct vs. indirect } \\
\text { forecasting }\end{array}$ \\
\hline $\begin{array}{l}\text { Kim \& Ngo } \\
(2001)\end{array}$ & M & Australia (I) & $\begin{array}{c}\text { ES VAR VECM } \\
\text { SARIMA }\end{array}$ & $\mathrm{FC}$ & $\begin{array}{l}\text { Comparing univariate and } \\
\text { multivariate forecasts }\end{array}$ \\
\hline $\begin{array}{l}\text { Kon \& Turner } \\
(2005)\end{array}$ & Q & Singapore (I) & ANN BSM Naïve1 ES & $\mathrm{FC}$ & Neural network forecasting \\
\hline $\begin{array}{l}\text { Kulendran \& Shan } \\
\text { (2002) }\end{array}$ & M & China (I) & $\begin{array}{c}\text { SARIMA ARIMA AR } \\
\text { BSM Naïve1 }\end{array}$ & $\mathrm{FC}$ & $\begin{array}{l}\text { Time-series modelling and } \\
\text { Forecast accuracy comparison }\end{array}$ \\
\hline $\begin{array}{l}\text { Kulendran \& } \\
\text { Wilson }(2000)\end{array}$ & M & Australia (I) & $\begin{array}{c}\text { CI/ECM Naïve1 } \\
\text { ARIMA }\end{array}$ & $\mathrm{FC}$ & $\begin{array}{l}\text { Modelling business travel } \\
\text { and accuracy comparison }\end{array}$ \\
\hline $\begin{array}{l}\text { Kulendran \& Witt } \\
\text { (2001) }\end{array}$ & Q & $\mathrm{UK}(\mathrm{O})$ & $\begin{array}{l}\text { CI/ECM ARIMA SR } \\
\text { BSM SARIMA Naïve1 }\end{array}$ & $\mathrm{FC}$ & $\begin{array}{l}\text { Cointegration vs. least } \\
\text { squares regression }\end{array}$ \\
\hline $\begin{array}{l}\text { Kulendran \& Witt } \\
\text { (2003a) }\end{array}$ & Q & Australia (I) & $\begin{array}{l}\text { ECM STSM SARIMA } \\
\text { ARIMA AR Naïve1BSM }\end{array}$ & $\mathrm{FC}$ & $\begin{array}{l}\text { Forecasting business tourism } \\
\text { and accuracy comparison }\end{array}$ \\
\hline $\begin{array}{l}\text { Kulendran \& Witt } \\
\text { (2003b) }\end{array}$ & Q & $\mathrm{UK}(\mathrm{O})$ & TFM ECM ARIMA & $\mathrm{FC}$ & Leading indicator Forecasts \\
\hline $\begin{array}{l}\text { Kulendran \& } \\
\text { Wong (2005) }\end{array}$ & Q & $\mathrm{UK}(\mathrm{O})$ & ARIMA SARIMA & $\mathrm{FC}$ & $\begin{array}{l}\text { Testing seasonality with } \\
\text { HEGY }\end{array}$ \\
\hline Lanza et al (2003) & Q & $\begin{array}{l}13 \text { European } \\
\text { countries }(\mathrm{O})\end{array}$ & LAIDS & No & $\begin{array}{l}\text { Econometric analysis of } \\
\text { tourism specialisation }\end{array}$ \\
\hline Law (2000) & A & $\begin{array}{l}\text { Taiwan- } \\
\text { Hong Kong }\end{array}$ & ANN Naïve1 ES MA SR & $\mathrm{FC}$ & Neural network forecasting \\
\hline Law (2001) & A & $\begin{array}{c}\text { Japan to } \\
\text { Hong Kong }\end{array}$ & $\begin{array}{c}\text { ANN Naïve1,2 MA ES } \\
\text { SR }\end{array}$ & $\mathrm{FC}$ & $\begin{array}{l}\text { Impacts of Asian Financial } \\
\text { Crisis and demand forecasting }\end{array}$ \\
\hline
\end{tabular}




\begin{tabular}{|c|c|c|c|c|c|}
\hline Law (2004) & A & $\begin{array}{l}\text { Hong Kong } \\
\text { (I) }\end{array}$ & $\begin{array}{l}\text { Naïve1,2 ES MA trend } \\
\text { extrapolation }\end{array}$ & $\mathrm{FC}$ & $\begin{array}{l}\text { Forecasting hotel room } \\
\text { occupancy rate }\end{array}$ \\
\hline Law \& Au (2000) & A & $\begin{array}{l}\text { Hong Kong } \\
\text { (I) }\end{array}$ & Rough sets & Expost & $\begin{array}{l}\text { Rough set theory and } \\
\text { tourism shopping modelling }\end{array}$ \\
\hline Law et al (2004) & A & $\begin{array}{l}\text { Japan to } \\
\text { Hong Kong }\end{array}$ & Rough sets & Expost & $\begin{array}{l}\text { Rough set theory and demand } \\
\text { modelling }\end{array}$ \\
\hline $\begin{array}{l}\text { Ledesma-Rodríguez } \\
\text { et al (2001) }\end{array}$ & A & Tenerife (I) & $\begin{array}{c}\text { Dynamic PDR Static } \\
\text { PDR }\end{array}$ & No & $\begin{array}{l}\text { Panel data analysis of tourism } \\
\text { elasticities }\end{array}$ \\
\hline Li et al (2004) & $\mathrm{A}$ & UK (O) & $\begin{array}{l}\text { EC-LAIDS Static } \\
\text { LAIDS }\end{array}$ & $\mathrm{FC}$ & $\begin{array}{l}\text { Error correction AIDS for } \\
\text { modelling and forecasting }\end{array}$ \\
\hline Li et al (2006a) & A & $\mathrm{UK}(\mathrm{O})$ & $\begin{array}{l}\text { TVP-LAIDS TVP-EC- } \\
\text { LAIDS Static/EC LAIDS }\end{array}$ & $\mathrm{FC}$ & $\begin{array}{l}\text { TVP error correction AIDS } \\
\text { for demand forecasting }\end{array}$ \\
\hline Li et al (2006b) & A & UK $(\mathrm{O})$ & $\begin{array}{c}\text { TVP-ECM TVP } \\
\text { ADLM VAR ECMs }\end{array}$ & $\mathrm{FC}$ & $\begin{array}{l}\text { Forecasting with a TVP error } \\
\text { correction model }\end{array}$ \\
\hline Lim (2004) & Q & $\begin{array}{l}\text { Korea to } \\
\text { Australia }\end{array}$ & ADLM & No & $\begin{array}{l}\text { Econometric analysis of } \\
\text { demand elasticities }\end{array}$ \\
\hline $\begin{array}{l}\text { Lim \& McAleer } \\
(2000)\end{array}$ & M & Australia (I) & SARIMA & No & $\begin{array}{l}\text { deterministic vs. stochastic } \\
\text { seasonality }\end{array}$ \\
\hline $\begin{array}{l}\text { Lim \& McAleer } \\
\text { (2001a) }\end{array}$ & Q & Australia (I) & VAR CI/VECM & No & $\begin{array}{l}\text { Cointegration analysis of } \\
\text { quarterly demand }\end{array}$ \\
\hline $\begin{array}{l}\text { Lim \& McAleer } \\
(2001 b)\end{array}$ & M & Australia (I) & ARMA ARIMA & No & $\begin{array}{l}\text { MA technique to estimate } \\
\text { seasonal components }\end{array}$ \\
\hline $\begin{array}{l}\text { Lim \& McAleer } \\
(2002)\end{array}$ & Q & Australia (I) & SARIMA ARIMA & $\mathrm{FC}$ & $\begin{array}{l}\text { Pre-testing of seasonality } \\
\text { and forecast accuracy }\end{array}$ \\
\hline Louvieris (2002) & M & Greece (I) & SARIMA Contingency & $\begin{array}{l}\text { Exante } \\
\text { FC }\end{array}$ & $\begin{array}{l}\text { A contingency approach to } \\
\text { forecasting }\end{array}$ \\
\hline Lyssiotou (2000) & Q & $\mathrm{UK}(\mathrm{O})$ & Dynamic AIDS & No & Dynamic AIDS analysis \\
\hline $\begin{array}{l}\text { Mangion et al } \\
(2005)\end{array}$ & A & $\mathrm{UK}(\mathrm{O})$ & EC-LAIDS HPM & No & $\begin{array}{l}\text { Competitiveness analysis using } \\
\text { AIDS \& hedonic pricing model }\end{array}$ \\
\hline $\operatorname{Min}(2005)$ & M & Taiwan (I) & SARIMA & Expost & $\begin{array}{l}\text { Crisis (SARS) impact } \\
\text { analysis }\end{array}$ \\
\hline Narayan (2004) & A & Fiji (I) & CI ECM & No & $\begin{array}{l}\text { Econometric analysis of } \\
\text { tourism demand }\end{array}$ \\
\hline $\begin{array}{l}\text { Naudé \& Saayman } \\
(2005)\end{array}$ & A & $\begin{array}{l}43 \text { African } \\
\text { countries }\end{array}$ & $\begin{array}{c}\text { Static/dynamic PDR } \\
\text { Cross-section regression }\end{array}$ & No & $\begin{array}{l}\text { Panel data regression analysis } \\
\text { of tourism demand }\end{array}$ \\
\hline Oh (2005) & Q & Korea (I) & VAR & No & $\begin{array}{l}\text { Contribution of tourism to } \\
\text { economic growth }\end{array}$ \\
\hline $\begin{array}{l}\text { Oh \& Morzuch } \\
(2005)\end{array}$ & M & Singapore (I) & $\begin{array}{l}\text { Naïve1,2 SR ES ARIMA } \\
\text { SARIMA SW combined }\end{array}$ & $\begin{array}{c}\mathrm{FC} \\
\text { Combination }\end{array}$ & $\begin{array}{l}\text { Forecasting competition and } \\
\text { suggestion on combination }\end{array}$ \\
\hline $\begin{array}{l}\text { Pai \& Hong } \\
\text { (2005) }\end{array}$ & M & Barbados (I) & ANN ARIMA SARIMA & $\mathrm{FC}$ & $\begin{array}{l}\text { Improved ANN and forecast } \\
\text { comparison }\end{array}$ \\
\hline Pai et al (2006) & M & Barbados (I) & $\begin{array}{c}\text { GA-SVR SARIMA } \\
\text { ARIMA }\end{array}$ & $\mathrm{FC}$ & $\begin{array}{l}\text { Forecasting with support } \\
\text { vector machines }\end{array}$ \\
\hline $\begin{array}{l}\text { Palmer et al } \\
(2006)\end{array}$ & Q & Singapore (I) & ANN & $\mathrm{FC}$ & $\begin{array}{l}\text { Selecting the best ANN model } \\
\text { for forecasting }\end{array}$ \\
\hline $\begin{array}{l}\text { Papatheodorou \& } \\
\text { Song (2005) }\end{array}$ & A & $\begin{array}{l}\text { World's } \\
\text { regions }\end{array}$ & ARIMA & Ex ante & $\begin{array}{l}\text { Forecasting world's future } \\
\text { demand }\end{array}$ \\
\hline $\begin{array}{l}\text { Patsouratis et al } \\
(2005)\end{array}$ & A & Greece (I) & SR & No & $\begin{array}{l}\text { Econometric analysis of } \\
\text { tourism demand }\end{array}$ \\
\hline $\begin{array}{l}\text { Payne \& Mervar } \\
(2002)\end{array}$ & Q & Croatia (I) & SR & No & $\begin{array}{l}\text { Econometric analysis of } \\
\text { tourism revenues }\end{array}$ \\
\hline $\begin{array}{l}\text { Pennington-Gray } \\
\text { et al (2002) }\end{array}$ & A & USA (O) & Cohort analysis & No & $\begin{array}{l}\text { Palmore's Cohort analysis of } \\
\text { travel patterns }\end{array}$ \\
\hline $\begin{array}{l}\text { Petropoulos et al } \\
(2005)\end{array}$ & A & Greece (I) & $\begin{array}{c}\text { TAS Naïve1,2 ES Com } \\
\text { TCM AR }\end{array}$ & $\begin{array}{l}\text { DCF } \\
\text { FC }\end{array}$ & $\begin{array}{l}\text { Technical analysis approach } \\
\text { in forecasting competition }\end{array}$ \\
\hline
\end{tabular}




\begin{tabular}{|c|c|c|c|c|c|}
\hline $\begin{array}{l}\text { Petropoulos et al } \\
\text { (2003) }\end{array}$ & A & Greece (I) & $\begin{array}{c}\text { DSS Naïve1,2 ES } \\
\text { ARIMA }\end{array}$ & $\mathrm{FC}$ & $\begin{array}{l}\text { Decision support system for } \\
\text { forecasting }\end{array}$ \\
\hline $\begin{array}{l}\text { Prideaux et al } \\
\text { (2003) }\end{array}$ & -- & Indonesia (I) & descriptive & No & $\begin{array}{l}\text { Limits of current forecasting } \\
\text { methods in crisis situations }\end{array}$ \\
\hline Riddington (2002) & A & UK (I) & $\begin{array}{l}\text { Supplemented LCM } \\
\text { LCM TVP }\end{array}$ & $\mathrm{FC}$ & $\begin{array}{l}\text { Forecasting demand for ski } \\
\text { tourism }\end{array}$ \\
\hline $\begin{array}{l}\text { Rodrigues \& } \\
\text { Gouveia (2004) }\end{array}$ & M & Portugal (I) & PAR AR & $\mathrm{FC}$ & $\begin{array}{l}\text { Periodic autoregressive } \\
\text { models for forecasting }\end{array}$ \\
\hline $\begin{array}{l}\text { Roget \& Gonzalez } \\
\text { (2006) }\end{array}$ & A & Spain (I) & dynamic PDR & No & $\begin{array}{l}\text { panel data analysis for rural } \\
\text { tourism demand }\end{array}$ \\
\hline Rosselló (2001) & M & $\begin{array}{l}\text { Balearic } \\
\text { Islands (I) }\end{array}$ & ADLM Naïve1 ARIMA & $\begin{array}{l}\text { FC } \\
\text { TPF }\end{array}$ & $\begin{array}{l}\text { Turning point forecasts of a } \\
\text { leading indicator model }\end{array}$ \\
\hline $\begin{array}{l}\text { Rosselló et al } \\
\text { (2005) }\end{array}$ & A & $\begin{array}{l}\text { Balearic } \\
\text { Islands (I) }\end{array}$ & SR+diffusion SR & No & $\begin{array}{l}\text { Modelling dynamics using a } \\
\text { diffusion-augmented model }\end{array}$ \\
\hline $\begin{array}{l}\text { Rosselló et al } \\
\text { (2004) }\end{array}$ & $\mathrm{M} / \mathrm{A}$ & $\begin{array}{l}\text { The Balearic } \\
\text { Islands (I) }\end{array}$ & ECM & No & $\begin{array}{l}\text { Econometric analysis of } \\
\text { seasonal patterns }\end{array}$ \\
\hline Sakai et al (2000) & A & Japan (O) & PDR & Ex ante & $\begin{array}{l}\text { Panel data analysis of effects of } \\
\text { demographic change }\end{array}$ \\
\hline Salman (2003) & M & Sweden (I) & $\mathrm{CI}$ & No & $\begin{array}{l}\text { Cointegration analysis of } \\
\text { demand }\end{array}$ \\
\hline $\begin{array}{l}\text { Schwartz \& } \\
\text { Cohen }(2004)\end{array}$ & -- & Israel (I) & Qualitative technique & No & $\begin{array}{l}\text { Subjective estimates of } \\
\text { occupancy forecast uncertainty }\end{array}$ \\
\hline $\begin{array}{l}\text { Shan \& Wilson } \\
\text { (2001) }\end{array}$ & M & China (I) & VAR & No & $\begin{array}{l}\text { Casualty between trade and } \\
\text { tourism }\end{array}$ \\
\hline Smeral (2004) & A & $\begin{array}{c}25 \text { OECD } \\
\text { countries }(\mathrm{I} / \mathrm{O})\end{array}$ & Complete system & Ex ante & Long-term demand forecasts \\
\hline $\begin{array}{l}\text { Smeral \& Weber } \\
(2000)\end{array}$ & A & $\begin{array}{c}20 \text { OECD } \\
\text { countries }(I / O)\end{array}$ & Complete system & Ex ante & Long-term demand forecasts \\
\hline $\begin{array}{l}\text { Smeral \& Wüger } \\
(2005)\end{array}$ & A & Australia (I) & $\begin{array}{l}\text { ADLM SARIMA } \\
\text { MARIMA TFM }\end{array}$ & $\mathrm{FC}$ & $\begin{array}{l}\text { Complexity of model structure } \\
\text { improves forecast accuracy }\end{array}$ \\
\hline $\begin{array}{l}\text { Song \& Witt } \\
(2003)\end{array}$ & A & Korea (I) & ADLM ECM & No & $\begin{array}{l}\text { General-to-specific } \\
\text { forecasting approach }\end{array}$ \\
\hline $\begin{array}{l}\text { Song \& Witt } \\
(2006)\end{array}$ & Q & Macau (I) & VAR & Ex ante & $\begin{array}{l}\text { Impulse response analysis } \\
\text { using VAR model }\end{array}$ \\
\hline $\begin{array}{l}\text { Song \& Wong } \\
(2003)\end{array}$ & A & $\begin{array}{l}\text { Hong Kong } \\
\text { (I) }\end{array}$ & TVP & No & $\begin{array}{l}\text { Econometric analysis using } \\
\text { TVP model }\end{array}$ \\
\hline Song et al (2000) & A & $\mathrm{UK}(\mathrm{O})$ & $\begin{array}{c}\text { CI/ECM Naïve } 1 \text { MA } \\
\text { AR ARMA VAR }\end{array}$ & $\mathrm{FC}$ & $\begin{array}{l}\text { Econometric modelling and } \\
\text { forecasting }\end{array}$ \\
\hline Song et al (2003a) & A & Denmark (I) & $\begin{array}{l}\text { SR CI/ECM Naïve1 VAR } \\
\text { ARIMA ADLM TVP }\end{array}$ & $\mathrm{FC}$ & $\begin{array}{l}\text { Econometric analysis and } \\
\text { forecast accuracy }\end{array}$ \\
\hline $\begin{array}{l}\text { Song et al } \\
\text { (2003b) }\end{array}$ & A & Thailand (I) & $\begin{array}{l}\text { ADLM ARIMA } \\
\text { CI/ECMs Naïve1 }\end{array}$ & Ex ante & $\begin{array}{l}\text { Econometric modelling and } \\
\text { forecasting }\end{array}$ \\
\hline Song et al (2003c) & A & $\begin{array}{l}\text { Hong Kong } \\
\text { (I) }\end{array}$ & ADLM & Ex ante & $\begin{array}{l}\text { Econometric modelling and } \\
\text { forecasting }\end{array}$ \\
\hline Tan et al (2002) & A & $\begin{array}{l}\text { Indonesia (I) } \\
\text { Malaysia (I) }\end{array}$ & SR & No & Econometric analysis \\
\hline $\begin{array}{l}\text { Tideswell et al } \\
\text { (2001) }\end{array}$ & A & Australia (I) & $\begin{array}{l}\text { Naïve1 linear trend ES } \\
\text { SR Delphi }\end{array}$ & $\begin{array}{c}\mathrm{FC} \\
\text { integration }\end{array}$ & $\begin{array}{l}\text { Integrating quantitative and } \\
\text { qualitative forecasts }\end{array}$ \\
\hline $\begin{array}{l}\text { Turner \& Witt } \\
\text { (2001a) }\end{array}$ & Q & $\begin{array}{l}\text { New Zealand } \\
\text { (I) }\end{array}$ & SEM & No & $\begin{array}{l}\text { SEM for disaggregated } \\
\text { demand (by travel purposes) }\end{array}$ \\
\hline $\begin{array}{l}\text { Turner \& Witt } \\
(2001 \mathrm{~b})\end{array}$ & Q & $\begin{array}{l}\text { New Zealand } \\
\text { (I) }\end{array}$ & BSM STSM Naïve1 & $\mathrm{FC}$ & $\begin{array}{l}\text { Univariate vs. multivariate } \\
\text { structural time series } \\
\text { forecasting }\end{array}$ \\
\hline $\begin{array}{l}\text { Vanegas \& Croes } \\
(2000)\end{array}$ & A & $\begin{array}{l}\text { USA to } \\
\text { Aruba }\end{array}$ & ADLM & $\begin{array}{l}\text { Ex ante } \\
\text { Expost }\end{array}$ & $\begin{array}{l}\text { Econometric modelling and } \\
\text { forecasting }\end{array}$ \\
\hline
\end{tabular}




\begin{tabular}{|c|c|c|c|c|c|}
\hline Veloce (2004) & Q & Canada (I) & $\begin{array}{c}\text { ECM SR AR VAR ES } \\
\text { ARIMA }\end{array}$ & $\mathrm{FC}$ & $\begin{array}{l}\text { ECM in Forecasting } \\
\text { competition }\end{array}$ \\
\hline $\mathrm{Vu}(2006)$ & Q & Japan (I) & BSM Naïve1 ES & $\begin{array}{l}\text { Expost } \\
\text { FC }\end{array}$ & $\begin{array}{l}\text { Effect of demand volume on } \\
\text { forecast accuracy }\end{array}$ \\
\hline $\begin{array}{l}\text { Vu \& Turner } \\
(2005)\end{array}$ & Q & Korea (I) & ES BSM & Expost & $\begin{array}{l}\text { Data disaggregation and } \\
\text { forecast accuracy }\end{array}$ \\
\hline $\begin{array}{l}\text { Vu \& Turner } \\
\text { (2006) }\end{array}$ & M & Thailand (I) & SARIMA BSM & $\begin{array}{l}\text { Ex ante } \\
\text { Expost }\end{array}$ & $\begin{array}{l}\text { City-based regional data } \\
\text { forecasting accuracy }\end{array}$ \\
\hline Wang (2004) & A & Taiwan (I) & GA FTS, Markov-GA & FC & $\begin{array}{l}\text { Fuzzy time series and hybrid } \\
\text { grey theory for forecasting }\end{array}$ \\
\hline Webber (2001) & Q & Australia (O) & $\mathrm{CI} / \mathrm{VAR}$ & No & $\begin{array}{l}\text { Exchange rate volatility and } \\
\text { cointegration analysis }\end{array}$ \\
\hline $\begin{array}{l}\text { Witt \& Turner } \\
(2002)\end{array}$ & A & China (I) & STSM & Ex ante & Trends and forecasts \\
\hline Witt et al (2003) & A & Denmark (I) & $\begin{array}{l}\text { CI/ECM Naïve1 ADLM } \\
\text { ARIMA SR VAR TVP }\end{array}$ & $\mathrm{FC}$ & $\begin{array}{l}\text { Statistical tests for forecast } \\
\text { accuracy \& directional change }\end{array}$ \\
\hline Witt et al (2004) & A & Denmark (I) & VAR & Ex ante & $\begin{array}{l}\text { Forecasting tourism- } \\
\text { generated employment }\end{array}$ \\
\hline Wong et al (2006) & A & $\begin{array}{l}\text { Hong Kong } \\
\text { (I) }\end{array}$ & $\begin{array}{l}\text { Bayesian VAR } \\
\text { Unrestricted VAR }\end{array}$ & $\mathrm{FC}$ & $\begin{array}{l}\text { Bayesian VAR models for } \\
\text { forecasting }\end{array}$ \\
\hline Wong et al (2007) & Q & $\begin{array}{l}\text { Hong Kong } \\
\text { (I) }\end{array}$ & $\begin{array}{l}\text { SARIMA VAR ECM } \\
\text { ADLM combined }\end{array}$ & $\begin{array}{c}\text { FC } \\
\text { combination }\end{array}$ & Forecast combination \\
\hline
\end{tabular}

Table 2. Publications of Tourism Demand Forecasting Studies (2000-2006)

\begin{tabular}{ccc} 
Journal & No. of Publications & Annual Average \\
\hline Tourism Management & 27 & 3.9 \\
Tourism Economics & 27 & 3.9 \\
Journal of Travel Research & 16 & 2.3 \\
Annals of Tourism Research & 12 & 1.7 \\
Journal of Travel and Tourism Marketing & 12 & 1.7 \\
Other Tourism/Hospitality Journals & 9 & 1.3 \\
Generic Economics/Management Journals & 16 & 2.3 \\
\hline Total & $\mathbf{1 1 9}$ & $\mathbf{1 7}$ \\
\hline
\end{tabular}

Note: Two papers emerging in 2007 are not included in the above statistics. 


\section{Empirical Findings of Research}

\subsection{Some general observations}

Tourism demand modelling and forecasting research relies heavily on secondary data in terms of model construction and estimation. Although the explanatory variables included in the tourism demand models vary enormously with research objectives and researchers' backgrounds, the employment of certain indicators as the measurement of tourism demand variables in modelling and forecasting tourism demand have been less controversial as suggested in Witt and Song (2000).

The tourist arrivals variable is still the most popular measure of tourism demand over the past few years. Specifically, this variable was measured by total tourist arrivals from an origin to a destination, which could be decomposed further into holiday tourist arrivals, business tourist arrivals, tourist arrivals for visiting friends and relatives (VFR) purposes (e.g., Turner and Witt, 2001a, 2001b, and Kulendran and Wong, 2005, respectively), and tourist arrivals by air (Coshall, 2005; Rosselló-Nadal, 2001). Some studies used tourist expenditure in the destination as the demand variable (such as Li et al, 2004, 2006a and 2006b) and others employed tourist expenditure on particular tourism product categories, such as meal expenditure ( $\mathrm{Au}$ and Law, 2002), sightseeing expenditure (Au and Law, 2000), and shopping ( $\mathrm{Law}$ and $\mathrm{Au}, 2000$ ). Other tourism demand variables used in the literature include tourism revenues (Akal, 2004), tourism employment (Witt et al, 2004) and tourism import and export (Smeral, 2004).

Since research on tourism demand modelling and forecasting relies on secondary data, the availability of the data determines, to a large extent, the coverage of the geographical areas where sophisticated forecasting methodologies were used to generate reliable forecasts. The USA, UK, and France are the most popular researched countries as both destinations and countries of origin. Australia, Spain, Hong Kong, Korea and Mainland China are researched frequently as tourist destinations, whereas Germany and Japan are generally regarded as key source markets for international tourism. Overall, the USA and Western Europe, as traditional international tourism markets, still attract considerable attention in recent empirical research. Meanwhile, due to its fast and stable growth and promising future as the UNWTO predicts, Asia has gained increasing interest in tourism demand modelling and forecasting studies.

Over the past 7 years, tourism demand forecasting articles have mainly been published in some of the key tourism journals such as Tourism Management, Tourism Economics, Journal of Travel Research, Annals of Tourism Research and Journal of Travel and Tourism Marketing. However, a few economics and management journals, such as Applied Economics and International Journal of Forecasting have also published tourism demand forecasting studies but with a lower frequency. Table 2 summarises the frequencies of tourism forecasting studies published in the above mentioned journals during the period 2000-2006. 


\subsection{Methodological Developments}

Tourism demand modelling and forecasting methods can be broadly divided into two categories: quantitative and qualitative methods. In their study, Song and Turner (2006) concluded that the majority of the published studies used quantitative methods to forecast tourism demand. The quantitative forecasting literature is dominated by two subcategories of methods: non-causal time series models and the causal econometric approaches. The difference between them is whether the forecasting model identifies any causal relationship between the tourism demand variable and its influencing factors.

In the 121 post-2000 empirical studies reviewed in this paper, quantitative forecasting techniques were applied in all except two studies (Prideaux et al, 2003; Schwartz and Cohen, 2004). Out of these 121 studies, 72 used the time series techniques to model the demand for tourism. 68 of these 72 studies generated either ex post forecasts or ex ante forecasts while only 4 of them did not generate any forecast. Meanwhile, a variety of econometric models appeared in 71 studies. Among them 30 concentrated on the identification of the relationships between tourism demand and its influencing factors while 41 evaluated the forecasting performance of the econometric models in addition to the identification of the causal relationships. Amongst these 71 studies that employed econometric models, more than 30 of them applied both the time series and econometric approaches in estimating the tourism demand models and compared the forecasting performance of these models. In addition to the studies utilising the time series and econometric techniques, 11 studies also employed other forecasting techniques, which mostly fall into the category of artificial intelligence methods. Compared with the published studies prior to 2000 , forecasting methodologies have been more diverse in the new millennium.

\section{Time series models}

A time series model explains a variable with regard to its own past and a random disturbance term. Particular attention is paid to exploring the historic trends and patterns (such as seasonality) of the time series involved, and to predict the future of this series based on the trends and patterns identified in the model. Since time series models only require historical observations of a variable, it is less costly in data collection and model estimation.

Time series models have been widely used for tourism demand forecasting in the past four decades with the dominance of the integrated autoregressive moving-average models (ARIMAs) proposed by Box and Jenkins (1970). Different versions of the ARIMA models have been applied in over two-thirds of the post-2000 studies that utilised the time series forecasting techniques. Depending on the frequency of the time series, either simple ARIMA or seasonal ARIMA (i.e. SARIMA) models could be used with the latter gaining an increasing popularity over the last few years, as seasonality is such a dominant feature of the tourism industry that decision makers are very much interested in the seasonal variation in tourism demand. With regard to the forecasting performance of the ARIMA and SARIMA models, empirical studies present contradictory evidence. For example, Cho (2001) showed that the ARIMA model outperformed two other time series models in all cases. Goh and Law (2002) suggested that the SARIMA models 
outperformed eight other time series methods while the non-seasonal (simple) ARIMA model's performance was above the average of all forecasting models considered. However, Smeral and Wüger (2005) found that the ARIMA or SARIMA model could not even outperform the Naïve 1 (no-change) model.

Considering the inconsistency in forecasting performance of the ARIMA/SARIMA models, researchers have recently tried to improve the forecasting performance of the ARIMA/SARIMA by using alternative time series approaches. One of the efforts has been to extend the univariate time series models to a multivariate dimension, and to examine if the additional information involved in the "parallel" time series (e.g. tourism demand for a destination by a number of origin countries/regions) may contribute to the improvement of forecast accuracy. For example, Goh and Law (2002) introduced a multivariate SARIMA (i.e. MARIMA) model which includes an intervention function to capture the potential spill-over effects of the "parallel" demand series on a particular tourism demand series. Their study showed that the multivariate SARIMA model significantly improved the forecasting performance of the simple SARIMA as well as other univariate time series models. However, in a similar attempt, Gustavsson and Nordström (2001) found that their multivariate ARIMA model could not beat its univariate counterpart. Moreover, Du Preez and Witt (2003) investigated the intervention effects of the time series models on forecasting performance within a state space framework. It was found that the multivariate state space time series model was outperformed by the simple ARIMA model. The authors argued that the unsatisfactory forecasting performance of the multivariate state space time series model was attributed mainly to the absence of a "rich" cross-correlation structure amongst "parallel" demand series.

Another extension of the univariate time series analysis of tourism demand has been the application of the Generalised Autoregressive Conditional Heteroskedastic (GARCH) model. GARCH models have been widely used in the financial modelling context to investigate the volatility of the time series. Chan et al (2005) applied three multivariate GARCH models to examine the volatility of tourism demand and the effects of various shocks in the tourism demand models. They found that tourism demand was affected by the conditional variances of the models that underline the demand for Australian tourism by the four leading tourism source markets. However, the forecasting performance of these multivariate GARCH models was not assessed.

Naïve 1 (or no-change), naïve 2 (or constant-growth-rate), exponential smoothing models, and simple autoregressive models have also appeared frequently in the post-2000 studies, but as in earlier tourism forecasting studies, they are usually used as benchmarks for forecasting accuracy evaluation.

\section{Econometric models}

One of the major advantages of the econometric approaches over the time series models lies in their ability to analyse the causal relationships between the tourism demand (dependent) variable and its influencing factors (explanatory variables). Econometric analysis "fulfils many useful roles other than just being a device for 
generating forecasts; for example, such models consolidate existing empirical and theoretical knowledge of how economies function, provide a framework for a progressive research strategy, and help explain their own failures" (Clements and Hendry, 1998, p16). As far as tourism demand is concerned, econometric analysis has its empirical usefulness in interpreting the change of tourism demand from an economist's perspective, proving policy recommendations as well as evaluating the effectiveness of the existing tourism policies. On the contrary, a time series model cannot help under circumstances in which interdependent relationships among tourism demand and other related factors are major concerns of businesses and governments.

As far as the influencing factors are concerned, recent econometric studies of tourism demand have shown that tourists' income, tourism prices in a destination relative to those in the origin country, tourism prices in the competing destinations (i.e., substitute prices) and exchange rates are the most important determinants of tourism demand. This finding is consistent with the previous reviews such as $\mathrm{Li}$ et al (2005) and Lim (1999). Identifying the determinants of tourism demand and estimating magnitudes of their influence on tourism demand are of great interest to decision-makers in tourist destinations. For example, if tourism prices and substitute prices are identified as significant determinants, the destination concerned should pay close attention to its competitors' pricing strategies. Once a competitor launches a new strategy such as a promotion campaign, the destination concerned should take prompt actions accordingly in order to sustain its competitiveness. Therefore, the employment of appropriate econometric models in tourism demand forecasting is crucial not only for academic researchers but also for tourism practitioners.

In order to avoid the spurious regression which often appears in traditional regression analysis based on ordinary least squares (OLS), great effort has been made to further advance the econometric approach in the context of tourism modelling and forecasting. Modern econometric methods, such as the autoregressive distributed lag model (ADLM), the error correction model (ECM), the vector autoregressive (VAR) model, and the time varying parameter (TVP) models, have emerged as the main forecasting methods in the current tourism demand forecasting literature (the technical illustration of these methods could be found in Song and Witt, 2000). Given the number of destinations (or source markets) being considered in an outbound (or inbound) tourism demand analysis, the same number of models are required, as each model concerns only one origin-destination pair. Apart from the VAR model, these modern econometric models are known as the single-equation modelling approach, and the explanatory variables included in the models should be exogenous. The VAR model, on the other hand, treats all variables as endogenous, and each variable is specified as a linear relationship of the others.

All of the above models frequently appear in recent tourism literature. For example, ECM was used in the studies of Kulendran, and Wilson (2000), Kulendran and Witt (2003b), Lim and McAleer (2001), Song and Witt (2000). The VAR model can be found in Shan and Wilson (2004), Song and Witt (2006), Witt et al (2004). ADLM was employed in such studies as Song et al (2003a) and Song et al (2003c). The latest development of the single-equation modelling approach in the tourism context can be 
seen in Li et al (2006b), who integrated the merits of the TVP model and ECM to develop a more advanced TVP-ECM. With regard to forecasting performance, these modern econometric models generally predict well. For instance, Kulendran, and Wilson (2000) showed that ECM outperforms SARIMA and Naïve 1. Song et al (2000) also showed superior performance of ECM. Song et al (2003a) concluded that the TVP model generates the most accurate one-step-ahead forecasts compared with five other econometric models, an ARIMA model and the Naïve 1 model. Li et al (2006b) found the overwhelming forecasting strength of TVP-ECM over a number of econometric alternatives and time-series models, as far as both the demand level and demand growth forecasts are concerned. Following the TVP-ECM, the TVP long-run model turned out to be the second most accurate model as far as the overall forecasting evaluations across four forecasting horizons were concerned. Up to now, the TVP long-run forecasting model and TVP-ECM short-run model have not been applied extensively in the tourism context, and further effort is needed to investigate their performance in forecasting tourism demand in a variety of tourism settings. Many of the above studies suggested that the classical VAR model did not perform well in the forecasting competition as compared with other modern econometric techniques. Wong et al (2006) developed three Bayesian VAR models by introducing different restrictions (priors) to the unrestricted VAR model, and found significant improvements of forecast accuracy. However, their forecasting performance relative to other modern econometric models such as ECM and TVP models was not evaluated in this study and this should be of interest to researchers in the future.

The almost ideal demand system (AIDS) model was developed by Deaton and Muellbauer (1980). It is a new modelling technique that has been recently applied to tourism demand analysis. Different from the single-equation econometric models, AIDS is a system-of-equations approach, normally employed to examine tourism demand in a number of neighbouring destinations by a source market, and uses tourism expenditure shares as dependent variables. The AIDS approach has a much stronger underpinning of economic theory. Hence, it is more powerful than its single-equation counterparts with respect to tourism demand elasticity analysis, such as substitution and complementary effects between alternative destinations under study. The AIDS modelling approach first appeared in the tourism literature in the early 1980s, and by the end of the last century there had been only five applications: Fujii et al (1985), O'Hagan and Harrison (1984), Papatheodorou (1999), Syriopoulos and Sinclair (1993) and White (1985). All of these studies adopted the original static version of AIDS specification. However, the past few years have seen an increasing interest in applying and further developing this method for tourism demand analysis. Eleven studies have employed various versions of AIDS for tourism demand modelling and forecasting during the period 2000-2006, and particular attention has been paid to the dynamics of tourism demand systems. For example, De Mello and Fortuna (2005), Durbarry and Sinclair (2003), Li et al (2004), and Mangion et al (2005) all combined ECM with the linear AIDS (LAIDS) model (i.e., EC-LAIDS). Li et al (2006a) further combined the TVP model along with the long-run LAIDS and ECLAIDS to establish TVP-LR-AIDS and TVP-EC-LAIDS models, respectively. In addition to the demand elasticity analysis, forecasting performance of various AIDS models was evaluated in five out of eleven studies. For instance, Li et al (2004) showed EC-LAIDS model's superior forecasting performance over its static counterpart. Li et al 
(2006a) demonstrated that TVP-LR-AIDS and TVP-EC-LAIDS outperformed their fixed-parameter counterparts in the overall evaluation of demand level forecasts. De Mello and Nell (2005) also examined the forecasting performance of the static AIDS in comparison with three VAR models. No significant difference was found between their one-step-ahead forecasting performance. As far as the multi-step forecasting is concerned, the static AIDS outperforms the unrestricted and first differenced VAR models but not the restricted VAR model with identified cointegration relationships. Comparison of forecasting performance between various dynamic LAIDS models and the cointegrated VAR model will be of great interest in future studies. Given the theoretical merits of AIDS with regard to its ability in examining the substitution effect, this method is highly suitable for analysing the destination competitiveness.

Panel data analysis has some advantages over the time series econometric models. It incorporates much richer information from both time series and cross sectional data. This approach also reduces the problem of multicollinearity and provides more degrees of freedom in the model estimation. Therefore, it is suitable for forecasting the demand for tourism when the time series for all variables are shorter, and cross-sectional information on these variables are also available. In spite of its advantages, the panel data approach has rarely been applied to tourism demand analysis. Four exceptions are found in the post-2000 literature. Ledesma-Rodríguez and Navarro-Ibánez (2001) used the panel data method to model the demand for Tenerife tourism and established both static and dynamic panel models. In addition, Naudé and Saayman (2005) and Roget and González (2006) both employed the same panel data approach to examine demand for tourism in 43 African countries and the demand for rural tourism in Galicia, Spain, respectively. Similarly, Sakai et al (2000) used the panel data approach to analyse the effects of demographic change on Japanese people's travel propensity. However, the forecasting ability of this approach has not yet been investigated in the tourism literature.

The structural equation model (SEM) has been widely used in the social and behavioural sciences, management, and a variety of other disciplines, including tourist behaviour and tourism marketing research. Unlike the more traditional multivariate regression models, SEMs are simultaneous equations models, in which variables may influence one another reciprocally. Since a SEM can represent causal relationships among variables, it is suitable for tourism demand modelling. However, only one study (Turner and Witt, 2001a) has been found in the post-2000 literature. Turner and Witt (2001a) developed a SEM to estimate the relationships between all the explanatory variables for three types of tourist flows (holidays, business visits and VFR). This study demonstrated the potential of SEMs in widening the variety of explanatory factors working together in a complex manner. Further applications of this approach and examination of its forecasting performance are recommended for future studies.

\section{Other quantitative models}

In addition to the time series and econometric models, a number of new quantitative forecasting methods, predominantly artificial intelligence (AI) techniques, have emerged in the tourism forecasting literature. AI has grown rapidly as a field of research across a variety of disciplines in recent years. Traditionally, AI used techniques derived from rule- 
based and logic programming systems, while the current interest has been focused on less precise heuristic methods, notably genetic algorithms, fuzzy logic, artificial neural networks and support vector machine(s) (Toshinori, 1998). The main advantage of AI techniques is that it does not require any preliminary or additional information about data such as distribution and probability. These AI techniques have been applied to tourism forecasting in some of the recent studies.

The artificial neural network (ANN) method The ANN method is a computing technique that tries to imitate the learning process of a human brain (Law, 2000). The unique features of ANNs, such as the ability to adapt to imperfect data, nonlinearity, and arbiter function mapping, make this method a useful alternative to the classical (statistic) regression forecasting models. The ANN method was first introduced to tourism forecasting in the late 1990s and some improved ANNs continued to appear in the post2000 literature. Kon and Turner (2005) provided a review of the applications of this method in tourism. Empirical evidence shows that ANNs generally outperform the classical time series and multiple regression models in tourism forecasting. For example, Burger et al (2001) showed that the ANN method was the best performing model over the naïve 1, decomposition, exponential smoothing, ARIMA, multiple regression and genetic regression models. Similar findings were also obtained by Cho (2003) who concluded that the ANN model outperforms the exponential smoothing and ARIMA models in modelling and forecasting the demand for Hong Kong tourism. Kon and Turner (2005) demonstrated that the ANN method outperforms the basic structural time series, naïve 1 and Holt-Winters models in forecasting the inbound tourism demand for Singapore. Despite the satisfactory forecasting performance, the ANN method does not have a systematic procedure for model building, and a reliable forecasting model is usually achieved through trial-and-error experiments (Kon and Turner, 2005; Palmer et al, 2006).

The rough set approach The rough set theory deals with the classificatory analysis of imprecise, uncertain, or incomplete knowledge (data) by incorporating the classical set theory (Au and Law, 2000, p70). The rough set approach is a decision rule induction method to model the relations that exist amongst a set of mixed numeric and non-numeric variables. Its applications to tourism demand analysis can be seen in Au and Law (2000; 2002) and Law and $\mathrm{Au}$ (2000) for tourism shopping, dining and sightseeing expenditure analyses, respectively. Different from the classical regression models, the rough set approach pays much attention to the categorical variables such as demographic features and predicts tourism demand levels (instead of exact values) in relation to each demographic category according to the modelled relationships among these variables. Therefore, it is regarded as a useful complementary tool to econometric models for analysing tourism demand from a micro perspective.

The fuzzy time series method The fuzzy time series method has strengths in analysing a short time series with limited past observations. Similarly, grey theory focuses on model uncertainty and information insufficiency. Wang (2004) applied the fuzzy time series and the grey theory to tourism demand forecasting. Three models including the fuzzy time series, a grey model and a Markov modified grey model were 
developed to model and forecast tourist arrivals to Taiwan from Hong Kong, Germany and the USA using only twelve annual data. The forecasting performance of the three models depends on the origin country concerned and none can outperform the others in all cases. Consistency of the forecasting performance of the fuzzy time series models needs further research.

Genetic Algorithms (GAs) GAs are adaptive heuristic search algorithms premised on the evolutionary ideas of natural selection and genetics. The GA is generally recognised as an optimisation approach. Recent studies (e.g., Burger et al, 2001; Hernández-López, 2004; Hernández-López and Cáceres-Hernández, 2007) demonstrated that GAs are suitable for explaining changes in the composition of tourism demand. The support vector machine (SVM) is another AI technique that can be used in solving the classification, nonlinear regression estimation and forecasting problems. A SVM approach with GAs is presented in Pai et al (2006) who forecasted the demand for tourism in Barbados. Empirical evidence shows that the SVM was superior to AIRMA and SARIMA models in forecasting tourism demand. The authors suggested that the proposed model should be extended to incorporate explanatory variables in future studies. Its forecasting performance compared to modern econometric models would also be worth investigating.

Despite the unique characteristics (such as no requirement for data distribution) and some empirical evidence of relatively high degrees of forecast accuracy, AI techniques embody some important limitations. For example, they lack a theoretical underpinning, and are unable to interpret tourism demand from the economic perspective, and therefore provide very little help in policy evaluation. This restricts the scope of practical applications of AI techniques in tourism demand analysis.

\subsection{Competition, combination and integration of forecasts}

Forecasting competitions between alternative methods were carried out in 55 out of the 121 post-2000 studies. Although various models showed some degrees of relative forecast accuracy under specific situations, no single method could outperform others on all occasions. Some common issues are identified in the recent forecasting competition studies. Firstly, only a limited number of models were selected for forecasting competition, and no clear justifications were given as to why these candidates instead of others were chosen in the forecasting competition. In most cases less than 5 models were selected, and these sometimes included alternative versions of the same type of models. Therefore, the conclusions drawn are subject to very specific conditions. Secondly, in a number of competitions, traditional OLS static regression was often selected to represent the econometric approach ignoring the well documented and widely used modern econometric techniques. It is not surprising that the OLS regression could hardly win the competition in these studies due to spurious regression and lack of dynamics. In fact, these problems could be easily overcome by most of the modern econometric techniques. Possibly due to researchers' fields of specialisation, these advanced econometric models are normally omitted from these competitions. Thirdly, in a forecasting competition where modern econometric approaches were emphasised and annual data were used, the time series models usually did not show their advantage and this may be due to the fact 
that the time series models such as SARIMA are useful mainly for higher frequency data rather than annual data. Lastly, forecast performance has mostly been evaluated by nonstatistical measures such as mean absolute percentage error (MAPE) and mean square percentage error (RSPE). Statistical tests for forecast differences are rarely used except De Mello and Nell (2005), Kon and Turner (2005) and Witt et al (2003). Without the support of statistical testing, it would be difficult to assert whether one model is significantly better than others in forecasting. Additional attention should be given to these issues in future forecasting competitions.

As previous review articles identified, the data frequency, origin/destination pairs, forecasting horizon, number of competing models included in the forecasting exercise, and the variables to be forecasted (demand level or growth) all influence a model's relative forecasting performance. Recent empirical studies have further confirmed that there is no exclusive winner in tourism demand forecasting competitions. Some researchers have attempted to combine the forecasts generated from different models in order to improve the forecasting accuracy. General forecasting literature suggests that forecast combination can improve forecasting accuracy (Armstrong, 2001). Oh and Morzuch (2005) showed that the combined forecasts (based on the simple average) of four competing time series models always outperform the poorest individual forecasts, and sometimes even perform better than the best individual model. Wong et al (2007) advanced the study on forecast combination in the context of Hong Kong inbound tourism forecasting and drew a similar conclusion that combined forecasts can generally outperform the worst individual forecasts, thereby risk of complete forecast failure could be reduced through forecast combination. Although both studies showed the usefulness of forecast combination in tourism forecasting, more efforts are needed to look at the forecasting accuracy improvement through forecast combinations. For example, more complex combination techniques, additional advanced individual forecasting methods and multiple forecasting horizons should all be considered in future studies.

To overcome the limitations of quantitative forecasting approaches and further improve forecast accuracy, researchers have also tried to integrate the quantitative forecasting methods with qualitative alternatives. The method that "actively engages decision makers in the forecasting exercise contributes more to the broader strategic planning process than one that does not" (Tideswell et al, 2001, p163). The application of this approach is reported in the study of Tideswell et al (2001). The integrative approach introduced in this study combines statistical techniques with expert opinions in a quasiDelphi process. This approach was employed to forecast South Australia's international and domestic tourism markets. The empirical results showed that this approach performed well overall for the international markets (MAPE 3.0\% only), but unsatisfactorily for some domestic market segments.

\section{Forecasting tourism cycles, turning points and directional changes}

Tourism growth cycles and thereby the turning point or directional change forecasting is another important aspect in tourism forecasting research. It has a high practical value because tourism-related firms are keen to know not only the overall trends of tourism demand, but also the timing of the directional change in tourism growth. This knowledge 
will contribute to the effectiveness of both business planning in the private sector and macroeconomic policy making in the public sector. Despite the practical importance, there has been limited literature focusing on this issue. Coshall (2000) employed spectral analysis to detect cycles within and between the time series of tourism flows by air and sea from the UK to France, Belgium and the Netherlands. The univariate spectral analysis found no business cycle-type oscillations except the seasonal cycles. However, the crossspectral analysis identified the cycles of dependence of passenger flows on the exchange rate changes. Gouveia and Rodrigues (2005) used a non-parametric method to identify the tourism growth cycles using the data on monthly tourist nights spent in hotel accommodation in the Algarve from the main source markets. It concluded that there is a time lag between tourism demand cycles and economic cycles. Rosselló (2001) used the leading indicator approach to forecast the turning points of international visitor arrivals to the Balearic Islands from the UK and Germany. The empirical results suggested that the leading indicator approach is favourable in turning point forecasting. Two studies further examined the forecast accuracy in terms of directional change accuracy. Witt et al (2003) suggested that the TVP model is preferable to 4 other econometric models and two time series models in the short-run forecasting of directional change, but there is no clear-cut evidence when longer horizons are concerned. Petropoulos et al (2005) showed that the model which incorporates technical analysis techniques outperforms classic time series models in directional change forecasting competition. Future forecast accuracy evaluation studies should not only focus on forecast error magnitude, but also on turning points and directional change errors.

\section{Seasonality analysis}

Out of the 121 post-2000 studies 117 used historical data in modelling and forecasting tourism demand, within which 58 employed annual data, 30 used quarterly data, and another 30 utilised monthly data (including 1 that uses both annual and monthly data). As an exception, Hu et al (2004) used 610 daily customer counts data to examine the shortterm demand for a casino buffet restaurant. It can be seen that the main data frequency in the existing literature is still annual data, consistent with earlier tourism forecasting studies. However, in practice annual data cannot always meet the requirements of the decision and policy makers in tourism, as in many situations they desire the prediction of tourism demand within the next 12 months in order for their short-term business planning or resource management (such as staffing and stock arrangement). The dominant use of annual data, mostly for econometric analysis, is probably due to the fact that the explanatory variables at higher frequencies are not easy to obtain. Most existing papers in which monthly data are employed focus on time series methods where explanatory variables are not needed. Amongst the 71 econometric studies, only 6 used monthly data. Quarterly data were used more frequently than the monthly data, but they have only been included in 18 studies. Other studies utilising monthly and quarterly data emphasised mainly the patterns of seasonal fluctuations in tourism demand.

Seasonality is a notable characteristic of tourism demand and cannot be ignored in the modelling process when monthly or quarterly data are used. How to handle the seasonal fluctuations of tourism data has always been an important and complex issue in tourism demand analysis. In the tourism demand forecasting literature, seasonality is often treated 
either as a deterministic component or a stochastic component in the time series. If seasonality is considered as stochastic, the time series needs to be seasonally differenced to account for seasonal unit roots in the time series. If the seasonality is regarded as deterministic, introducing seasonal dummies into the time series models would be sufficient in accounting for the seasonal variations. To test for the presence of seasonal unit roots, the HEGY test (Hylleberg, Engle, Granger, and Yoo, 1990) is widely used. However, empirical studies showed inconclusive evidence as to whether seasonality should be treated as stochastic or deterministic, and whether imposing seasonal unit roots may lead to more accurate forecasts. For instance, Alleyne (2006) applied the HEGY procedure to detect stochastic seasonality of quarterly tourist arrivals to Jamaica and suggested that forecast accuracy can be improved by pre-testing seasonal unit roots in the time series. Lim and McAleer (2001b) concluded from their empirical study that it is more appropriate to regard tourism demand seasonality as stochastic. However, using the same unit root test, Kim and Ngo (2001) detected deterministic seasonality in their study of airline passenger flows between three Australian cities. Coshall (2005) presented mixed evidence in his empirical study of UK short-haul tourism demand by air and stated that no generalisation could be made about the stochastic or deterministic nature of seasonality in the tourism demand data.

Kim and Moosa (2001) further argued that the HEGY test suffers from deficiencies in small samples, which are often the case in the tourism context. As a result, incorrect inferential outcomes are likely to be obtained. This drawback of the HEGY test provides another possible explanation for the above contradictory findings in addition to the likelihood of different properties embodied in different datasets. Kulendran and Wong (2005) also challenged the power of the HEGY test in the model selection process. Kim and Moosa (2001) proposed an alternative test to the HEGY test-the Caner test, which also generates contradictory results. According to the Caner test, stochastic seasonality is appropriate in most cases of their Australian tourist arrivals series. However, in a subsequent forecasting comparison exercise, they found that the stochastic treatment of seasonality did not improve the forecast accuracy. The most accurate forecasts resulted from a regression based (time-series) model, in which seasonality was treated as a deterministic component. Gustavsson and Nordström (2001) also demonstrated that imposing unit roots on all frequencies could lead to more accurate short-term forecasts than models built constitutionally on the outcome from seasonal unit root tests. These findings responded to the statement by Clements and Hendry (1997) that "there is little evidence in the literature on the effect of imposing seasonal unit roots on forecast accuracy" (cited from Gustavsson and Nordström, 2001, p118). Therefore, Gustavsson and Nordström (2001) suggested that rather than carrying out the unit root test, attention should be paid to selecting a more flexible model structure (e.g., a state space model), that can deal with such features as changing seasonal patterns and trends.

Unlike the above traditional procedures of seasonal (integer) differencing of a time series, Gil-Alana et al (2004) introduced an alternative method, known as the test for fractional integration, to test the seasonal components in the time series. The test employed in their study allows for the consideration of unit and fractional orders of integration in a time series. They found that the orders of integration are higher than 0 but 
smaller than 1 in the Spanish tourism demand series. This indicates that the tourism demand series demonstrate seasonal long memory and mean reverting behaviour. The policy implication of this is that "there exists less need for policy action since the series will return to its path sometime in the future" (Gil-Alana, 2005, p868). Furthermore, GilAlana (2005) examined seasonal fractional integration in monthly tourist arrivals to the USA and reached a similar conclusion. In a forecasting comparison based on a longer dataset, this study further showed that the seasonal fractional models always outperform the non-fractional ones. This finding raised a concern as to whether the SARIMA models used in the previous studies (supported by the HEGY test) actually reflected the characteristics of the seasonal-fractional integration in the time series. If they did not, all the time series models specified in the previous studies suffered from the problem of model mis-specification. More empirical studies are needed to respond to this concern.

Another approach to modelling seasonal fluctuations is to use the periodic autoregressive (PAR) model. This model allows for parameters to vary according to the seasons of a year, and therefore "may reflect seasonal economic decision making more adequately than constant parameter specifications" (Osborn and Smith, 1989, pp126-127). Rodrigues and Gouveia (2004) applied a parsimonious PAR model on a monthly series of lodging in the Algarve from several countries and demonstrated its superiority in forecasting performance to other PARs and an autoregressive model in first difference with seasonal intercepts.

\section{Events' impact analysis and risk forecasting}

Man made crises and natural disasters have affected international tourism demand considerably. Increasing attention has been paid to quantifying the effects of these external shocks on tourism demand using various forecasting techniques (e.g., Huang and Min, 2002; Eugenio-Martin et al, 2005). The general procedure for such post-event analysis is to establish a reliable demand model, either a time series or an econometric model, using the historical data prior to the event, and then use this model to predict the tourism demand during the affected period. The predicted values are regarded as the level of tourism demand if the event would have not occurred. Thus, the differences between the predicted and actual demand provide the estimates of the effects of the event. Huang and Min (2002) investigated the earthquake devastation and recovery in tourism in Taiwan, and Min (2005) examined the effect of SARS on tourism demand in Taiwan, with both applying the SARIMA models. Eugenio-Martin et al (2005) used causal structural time series models to qualify the effects of the September 11 terrorist attacks and the foot and mouth disease on the demand for Scottish tourism amongst American, French and German tourists. Law (2001) employed several forecasting techniques to study the impact of the Asian Financial Crisis on the demand for Hong Kong tourism by Japanese travellers. Goh and Law (2002) estimated the SARIMA and MARIMA models with interventions to account for the influences of the Asian Financial Crisis along with other one-off events on Hong Kong inbound tourism. The limitation for such impact analysis is that it is impossible to separate the effects of several crises if one takes place soon after another. Likewise, Lim and McAleer (2002) employed the SARIMA models to analyse the effects of the one-off events on the demand for Australian tourism by the Asian source markets. This type of analysis also represents a great challenge on model 
specification. The model's forecasting accuracy determines the precision of the impact analysis.

Considering the potential effects of crises, disasters and other one-off events, not only is post-event impact analysis necessary but also pre-event risk assessment is important. Risk forecasting is of great importance for tourism practitioners, such as tourism business executives and government offices that are involved in tourism. However, very little attention has been given to the latter. Prideaux et al (2003) argued that current forecasting methods have little ability to cope with unexpected crises and disasters. Although these events are unexpected, their occurrence may be associated with some level of certainty. Thus, the effects of these events on tourism demand are to some extent predictable based on appropriate scenario analysis. Prideaux et al (2003) provided a useful framework for forecasting unexpected tourism shocks. In this framework shocks are classified according to severity, probability, type of event and level of certainty. Different forecasting tools, such as risk assessment, historical research, scenarios and the Delphi approach are suggested to deal with different types of shocks in relation to the levels of uncertainty. In particular, integration between qualitative and quantitative forecasting approaches was recommended to produce a series of scenario forecasts based on different assumptions. Empirical exercises of forecasting the unexpected tourism shocked based on this framework deserve future studies.

\section{Data disaggregation and forecast accuracy}

Most published studies on tourism forecasting are based on aggregate data (total tourist arrivals or total tourist expenditure) at the destination level. However, tourism demand analysis at the disaggregate level (in terms of purpose of travel, country of origin, and so on), is also of great interest to decision makers as it provides more detailed and diverse information than the total tourism demand. If the trends of individual market segments are major concerns, disaggregated data should be used in forecasting tourism demand. However, if the disaggregated data are available but forecasting the demand for aggregate tourism demand is of primary interest, the aggregate forecasts could be achieved through two methods. The first method is to forecast the total demand directly through aggregation of the demand data; the second approach is to forecast each individual component of the total market demand first and then to sum the individual forecasts (i.e., indirect forecasting) to arrive at the total aggregate forecasts (Song et al 2003c). This method is known as indirect forecast of total demand. Some attempts have been made to examine the effect of data disaggregating on forecast accuracy in earlier studies (e.g., Blackwell, 1970 and Martin and Witt, 1989). Applying more advanced forecasting techniques, some recent studies have further explored this issue. For instance, Kim and Moosa (2005) employed a SARIMA model, a regression-based time series model and a structural time series model to compare the forecasting accuracy of direct and indirect forecasts using the data of tourist arrivals to Australia classified by the length of stay. All three models suggested that the indirect method is favourable. However, in another study by $\mathrm{Vu}$ and Turner (2005), the opposite conclusion was drawn when the Holt-Winters model and basic structural time series model were used to forecast the Korean inbound tourist arrivals data disaggregated by purpose of travel, age and gender. Kon and Turner (2005) suggested that there is no statistical evidence to support either method. 


\section{Conclusions}

This paper reviews 121 studies on tourism demand modelling and forecasting published since 2000. The latest developments of quantitative forecasting techniques are summarised in three categories: time series models, the econometric approach, and other emerging methods such as AI techniques. Although recent studies show that the newer and more advanced forecasting techniques tend to result in improved forecast accuracy under certain circumstances, no clear-cut evidence shows that any one model can consistently outperform other models in the forecasting competition. This conclusion confirms those drawn in the pre-2000 studies. New attempts have been made recently to further enhance forecast accuracy through forecast combination, and forecast integration of quantitative and qualitative approaches. Further research in this respect is encouraged.

In addition to forecast competition, there have been a few research areas in which inconclusive findings have been obtained. For example, seasonality has always been an emphasis of tourism demand analysis. However, there has been no clear-cut answer to the ways in which the seasonality in tourism demand modelling and forecasting could be better handled. Seasonal fractional integration, which has been introduced in the tourism context very recently, is an alternative means to model seasonality. Moreover, mixed evidence has been presented in recent studies as to whether data disaggregation may improve forecast accuracy. Research in these areas deserves more attention by researchers.

Considering the enormous consequences of various crises and disasters, events' impact evaluation has attracted much interest in tourism demand forecasting research. It is crucial for researchers to develop some forecasting methods that can accommodate unexpected events in predicting the potential impacts of these one-off events through scenario analysis. Other areas that have not been extensively researched include tourism cycle analysis, turning point and directional change forecasting. Greater attention has been put on forecasting the magnitude of tourism demand while limited research has been conducted in forecasting the directional change or turning point forecast accuracy. Considering the significant policy implications of these forecasts, additional efforts need to be made in this research area in the future.

\section{References}

Aguiló, E., Riera, A., and Rosselló, J. (2005). The short-term price effect of a tourist tax through a dynamic demand model: The case of the Balearic Islands. Tourism Management, 26, 359365.

Akal, M. (2004). Forecasting Turkey's tourism revenues by ARMAX model. Tourism Management, 25, 565-580.

Algieri, B. (2006). An econometric estimation of the demand for tourism: the case of Russia. Tourism Economics, 12, 5-20.

Alleyne, D. (2006). Can seasonal unit root testing improve the forecasting accuracy of tourist arrivals? Tourism Economics, 12, 45-64. 
Armstrong, J. S. (2001). Combining forecasts in J. S. Armstrong (eds) Principles of forecasting: a handbook for researchers and practitioners. Kluwer Academic Publisher: Amsterdam, pages $417-439$.

$\mathrm{Au}, \mathrm{N}$., and Law, R. (2000). The application of rough sets to sightseeing expenditures. Journal of Travel Research, 39, 70-77.

$\mathrm{Au}$, N., and Law, R. (2002). Categorical classification of tourism dining. Annals of Tourism Research, 29, 819-833.

Bicak, H. A., Altinay, M., and Jenkins, H. (2005). Forcasting tourism demand of North Cyprus. Journal of Hospitality and Leisure Marketing, 12, 87-99.

Blackwell, J. (1970). Tourist traffic and the demand for accommodation: Some projections. Economic and Social Review, 1, 323-343.

Blake, A., Durbarry, R., Eugenio-Martin, J. L., Gooroochurn, N., Hay, B., Lennon, J., Thea Sinclair, M., Sugiyarto, G., and Yeoman, I. (2006). Integrating forecasting and CGE models: The case of tourism in Scotland. Tourism Management, 27, 292-305.

Box, G. E. P., and Jenkins, G. M. (1970). Time Series Analysis, Forecasting and Control. San Francisco: Holden Day.

Burger, C. J. S. C., Dohnal, M., Kathrada, M., and Law, R. (2001). A practitioners guide to timeseries methods for tourism demand forecasting -A case study of Durban, South Africa. Tourism Management, 22, 403-409.

Chan, F., Lim, C., and McAleer, M. (2005). Modelling multivariate international tourism demand and volatility. Tourism Management, 26, 459-471.

Chen, K. Y., and Wang, C. H. (2007). Support vector regression with genetic algorithms in forecasting tourism demand. Tourism Management, 28, 215-226.

Cho, V. (2001). Tourism forecasting and its relationship with leading economic indicators. Journal of Hospitality and Tourism Research, 25, 399-420.

Cho, V. (2003). A comparison of three different approaches to tourist arrival forecasting. Tourism Management, 24, 323-330.

Chu, F. L. (2004). Forecasting tourism demand: A cubic polynomial approach. Tourism Management, 25, 209-218.

Clements, M. P., and Hendry, D. F. (1997). An empirical study of seasonal unit roots in forecasting. International Journal of Forecasting, 13, 341-355.

Clements, M. P., and Hendry, D. F. (1998). Forecasting Economic Time Series. Cambridge: Cambridge University Press.

Coshall, J. T. (2000). Spectral analysis of international tourism flows. Annals of Tourism Research, 27, 577-589.

Coshall, J. T. (2005). A selection strategy for modelling UK tourism flows by air to European destinations. Tourism Economics, 11, 141-158.

Croes, R. R., and Vanegas Sr., M. (2005). An econometric study of tourist arrivals in Aruba and its implications. Tourism Management, 26, 879-890.

Crouch, G. I. (1994). The study of international tourism demand: a review of practice. Journal of Travel Research, 33, 41-54.

Daniel, A. C. M., and Ramos, F. F. R. (2002). Modelling inbound international tourism demand to Portugal. International Journal of Tourism Research, 4, 193-209.

De Mello, M. M., and Fortuna, N. (2005). Testing alternative dynamic systems for modelling tourism demand. Tourism Economics, 11, 517-537.

De Mello, M. M., and Nell, K. S. (2005). The forecasting ability of a cointegrated VAR system of the UK tourism demand for France, Spain and Portugal. Empirical Economics, 30, 277-308.

De Mello, M. M., Pack, A., and Sinclair, M. T. (2002). A system of equations model of UK tourism demand in neighbouring countries. Applied Economics, 34, 509-521.

Deaton, A. S., and Muellbauer, J. (1980). An almost ideal demand system. American Economic Review, 70, 312-326. 
Divisekera, S. (2003). A model of demand for international tourism. Annals of Tourism Research, $30,31-49$.

Dritsakis, N. (2004). Cointegration analysis of German and British tourism demand for Greece. Tourism Management, 25, 111-119.

Dritsakis, N., and Athanasiadis, S. (2000). An econometric model of tourist demand: The case of Greece. Journal of Hospitality and Leisure Marketing, 7, 39-49.

Du Preez, J., and Witt, S. F. (2003). Univariate versus multivariate time series forecasting: An application to international tourism demand. International Journal of Forecasting, 19, 435451.

Durbarry, R., and Sinclair, M. T. (2003). Market shares analysis: The case of French tourism demand. Annals of Tourism Research, 30, 927-941.

Eugenio-Martin, J., Sinclair, M. T., and Yeoman, I. (2005) Quantifying the Effects of Tourism Crises: an application to Scotland. Journal of Travel \& Tourism Marketing, 19, 21-34.

Fujii, E., Khaled, M. and Mark, J. (1985). An almost ideal demand system for visitor expenditures. Journal of Transport Economics and Policy, 19, 161-171.

Gallet, C. A., and Braun, B. M. (2001). Gradual switching regression estimates of tourism demand. Annals of Tourism Research, 28, 503-507.

Garín-Muñoz, T., and Amaral, T. P. (2000). An econometric model for international tourism flows to Spain. Applied Economics Letters, 7, 525-529.

Gil-Alana, L. A. (2005). Modelling international monthly arrivals using seasonal univariate longmemory processes. Tourism Management, 26, 867-878.

Gil-Alana, L. A., Gracia, F. P. D., and Cunado, J. (2004). Seasonal fractional integration in the Spanish tourism quarterly time series. Journal of Travel Research, 42, 408-414.

Goh, C., and Law, R. (2002). Modeling and forecasting tourism demand for arrivals with stochastic nonstationary seasonality and intervention. Tourism Management, 23, 499-510.

Goh, C., and Law, R. (2003). Incorporating the rough sets theory into travel demand analysis. Tourism Management, 24, 511-517.

Gouveia, P. M. D. C. B., and Rodrigues, P. M. M. (2005). Dating and synchronizing tourism growth cycles. Tourism Economics, 11, 501-515.

Greenidge, K. (2001). Forecasting tourism demand: An STM approach. Annals of Tourism Research, 28, 98-112.

Gustavsson, P., and Nordström, J. (2001). The impact of seasonal unit roots and vector ARMA modelling on forecasting monthly tourism flows. Tourism Economics, 7, 117-133.

Han, Z., Durbarry, R., and Sinclair, M. T. (2006). Modelling US tourism demand for European destinations. Tourism Management, 27, 1-10.

Hernández-López, M. (2004). Future tourists' characteristics and decisions: The use of genetic algorithms as a forecasting method. Tourism Economics, 10, 245-262.

Hernández-López, M., and Cáceres-Hernández, J. J. (2007). Forecasting tourists' characteristics by a genetic algorithm with a transition matrix. Tourism Management, 28, 290-297.

Hu, C., Chen, M., and McCain, S. C. (2004). Forecasting in Short-Term Planning and Management for a Casino Buffet Restaurant. Journal of Travel \& Tourism Marketing, 16, 79-98.

Huang, J.H., and Min, J. C. H. (2002). Earthquake devastation and recovery in tourism: The Taiwan case. Tourism Management, 23, 145-154.

Hylleberg, S., Engle, R. F., Granger, C. W. J., and Yoo, B. S. (1990). Seasonal integration and cointegration. Journal of Econometrics, 44, 215-238.

Ismail, J. A., Iverson, T. J., and, Cai, L. A. (2000). Forecasting Japanese arrivals to Guam: An empirical model. Journal of Hospitality and Leisure Marketing, 7, 51-63.

Kim, J. H. and Moosa, I. A. (2001). Seasonal behaviour of monthly international tourist flows: specification and implications for forecasting models. Tourism Economics, 7, 381-396. 
Kim, J. H., and Moosa, I. A. (2005). Forecasting international tourist flows to Australia: A comparison between the direct and indirect methods. Tourism Management, 26, 69-78.

Kim, J. H. and Ngo, M. T. (2001). Modelling and forecasting monthly airline passenger flows among three major Australian cities. Tourism Economics, 7, 397-412.

Kon, S. C., and Turner W. L. (2005). Neural network forecasting of tourism demand. Tourism Economics, 11, 301-328.

Kulendran, N., and Shan, J. (2002). Forecasting China's Monthly Inbound Travel Demand. Journal of Travel \& Tourism Marketing, 13, 5-19.

Kulendran, N., and Wilson, K. (2000). Modelling business travel. Tourism Economics, 6, 47-59.

Kulendran, N., and Witt, S. F. (2001). Cointegration versus least squares regression. Annals of Tourism Research, 28, 291-311.

Kulendran, N., and Witt, S. F. (2003a). Forecasting the demand for international business tourism. Journal of Travel Research, 41, 265-271.

Kulendran, N., and Witt, S. F. (2003b). Leading indicator tourism forecasts. Tourism Management, 24, 503-510.

Kulendran, N., and Wong K. K. F. (2005). Modeling Seasonality in Tourism Forecasting. Journal of Travel Research, 44, 163-170.

Lanza, A., Temple, P., and Urga, G. (2003). The implications of tourism specialization in the long run: An econometric analysis for 13 OECD economies. Tourism Management, 24, 315-321.

Law, R. (2000). Back-propagation learning in improving the accuracy of neural network-based tourism demand forecasting. Tourism Management, 21, 331-340.

Law, R. (2001). The Impact of the Asian Financial Crisis on Japanese Demand for Travel to Hong Kong: A Study of Various Forecasting Techniques. Journal of Travel \& Tourism Marketing, 10, 47-66.

Law, R. (2004). Initially Testing an Improved Extrapolative Hotel Room Occupancy Rate Forecasting Technique. Journal of Travel \& Tourism Marketing, 16, 71-77.

Law, R., and Au, N. (2000). Relationship modeling in tourism shopping: a decision rules induction approach. Tourism Management, 21, 241-249.

Law, R., Goh, C., and Pine, R. (2004). Modeling Tourism Demand: A decision rules based approach. Journal of Travel \& Tourism Marketing, 16, 61-69.

Ledesma-Rodríguez F. J., Navarro-Ibáñez, M., and Pérez-Rodríguez, J. V. (2001). Panel data and tourism: a case study of Tenerife. Tourism Economics, 7, 75-88.

Li, G., Song, H., and Witt, S. F. (2004). Modeling Tourism Demand: A Dynamic Linear AIDS Approach. Journal of Travel Research, 43, 141-150.

Li, G., Song, H., and Witt, S. F. (2005). Recent developments in econometric modeling and forecasting. Journal of Travel Research, 44, 82-99.

Li, G., Song, H., and Witt, S. F. (2006a). Time varying parameter and fixed parameter linear AIDS: An application to tourism demand forecasting. International Journal of Forecasting, 22, 57-71.

Li, G., Wong, K. F., Song, H., and Witt, S. F. (2006b). Tourism demand forecasting: A time varying parameter error correction model. Journal of Travel Research, 45: 175-185.

Lim, C. (1997a). Review of international tourism demand models. Annals of Tourism Research, 24, 835-849.

Lim, C. (1997b). An econometric classification and review of international tourism demand models. Tourism Economics, 3, 69-81.

Lim, C. (1999). A Meta analysis review of international tourism demand. Journal of Travel Research, 37, 273-84.

Lim, C. (2004). The major determinants of Korean outbound travel to Australia. Mathematics and Computers in Simulation, 64, 477-485.

Lim, C., and McAleer, M. (2000). A seasonal analysis of Asian tourist arrivals to Australia. Applied Economics, 32, 499-509. 
Lim, C., and McAleer, M. (2001a). Cointegration analysis of quarterly tourism demand by Hong Kong and Singapore for Australia. Applied Economics, 33, 1599-1619.

Lim, C., and McAleer, M. (2001b). Monthly seasonal variations: Asian tourism to Australia. Annals of Tourism Research, 28, 68-82

Lim, C., and McAleer, M. (2002). Time series forecasts of international travel demand for Australia. Tourism Management, 23, 389-396.

Louvieris, P. (2002). Forecasting International Tourism Demand for Greece: A Contingency Approach. Journal of Travel \& Tourism Marketing, 13, 21-40.

Lyssiotou, P. (2000). Dynamic analysis of British demand for tourism abroad. Empirical Economics, 15, 421-436.

Mangion, M. L., Durbarry, R., and Sinclair, M. T. (2005). Tourism competitiveness: price and quality Tourism competitiveness: price and quality. Tourism Economics, 11, 45-68.

Martin, C. A., and Witt, S. F. (1989). Forecasting tourism demand: A comparison of the accuracy of several quantitative methods. International Journal of Forecasting, 5, 7-10.

Min, J. C. H. (2005). The Effect of the SARS Illness on Tourism in Taiwan: An Empirical Study. International Journal of Management, 22, 497-506.

Narayan, P. K. (2004). Fiji's tourism demand: the ARDL approach to cointegration. Tourism Economics, 10, 193-206.

Naude, W. A., and Saayman, A. (2005). Determinants of tourist arrivals in Africa: a panel data regression analysis. Tourism Economics, 11, 365-391.

O'Hagan, J. W., and Harrison, M. J. (1984). Market Shares of US Tourism Expenditure in Europe: An Econometric Analysis. Applied Economics, 16: 919-931.

Oh, C. O., and Morzuch, B. J. (2005). Evaluating time-series models to forecast the demand for tourism in Singapore: Comparing within-sample and post-sample results. Journal of Travel Research, 43, 404-413.

Oh, C.O. (2005). The contribution of tourism development to economic growth in the Korean economy. Tourism Management, 26, 39-44.

Osborn, D.R., and Smith, J. P. (1989). The performance of periodic autoregressive models in forecasting seasonal UK consumption. Journal of Business and Economic Statistics, 7, $1117-1127$.

Pai, P. F., and Hong, W. C. (2005). An improved neural network model in forecasting arrivals. Annals of Tourism Research, 32, 1138-1141.

Pai, P. F., Hong, W. C., Chang, P. T., and Chen, C. T. (2006). The application of support vector machines to forecast tourist arrivals in Barbados: An empirical study. International Journal of Management, 23, 375-385.

Palmer, A., Jose Montano, J. J., and Sese, A. (2006). Designing an artificial neural network for forecasting tourism time series. Tourism Management, 27, 781-790.

Papatheodorou, A. (1999). The demand for international tourism in the Mediterranean region. Applied Economics, 31, 619-630.

Papatheodorou, A., and Song, H. (2005). International tourism forecasts: Time-series analysis of world regional data. Tourism Economics, 11, 11-23.

Patsouratis, V., Frangouli, Z., and Anastasopoulos, G. (2005). Competition in tourism among the Mediterranean countries. Applied Economics, 37, 1865-1870.

Payne, J. E., and Mervar, A. (2002). A Note on modelling tourism revenues in Croatia. Tourism Economics, 8, 103-09.

Pennington-Gray, L., Kerstetter, D. L., and Warnick, R. (2002). Forecasting travel patterns using Palmore's cohort analysis. Journal of Travel \& Tourism Marketing, 13, 125-143.

Petropoulos, C., Nikolopoulos, K., Patelis, A., and Assimakopoulos, V. (2005). A technical analysis approach to tourism demand forecasting.. Applied Economics Letters, 12, 327-333. 
Petropoulos, C., Patelis, A., Metaxiotis, K., Nikolopoulos, K., and Assimakopoulos, V. (2003). SFTIS: A decision support system for tourism demand analysis and forecasting. The Journal of Computer Information Systems, 44, 21-32.

Prideaux, B., Laws, E., and Faulkner, B. (2003). Events in Indonesia: exploring the limits to formal tourism trends forecasting methods in complex crisis situations. Tourism Management, 24, 475-487.

Riddington, G. (2002) Learning and ability to pay: developing a model to forecast ski tourism. Journal of Travel \& Tourism Marketing, 13, 109-124.

Rodrigues, P. M. M., and Gouveia, P. M. D. C. B. (2004). An application of PAR models for tourism forecasting. Tourism Economics, 10, 281-303.

Roget, F. M., and Gonzalez, X. A. R. (2006). Rural tourism demand in Galicia, Spain. Tourism Economics, 12, 21-31.

Rosselló, J. (2001). Forecasting turning points in international visitor arrivals in the Balearic Islands. Tourism Economics, 7, 365-380.

Rosselló, J., Aguiló, E., and Riera, A. (2005). Modeling tourism demand dynamics. Journal of Travel Research, 44, 111-116.

Rosselló, J., Font, A. R., and Rosselló, A. S. (2004). The economic determinants of seasonal patterns. Annals of Tourism Research, 31, 697-711.

Sakai, M., Brown, J., and Mak, J. (2000). Population aging and Japanese international travel in the 21st century. Journal of Travel Research, 38, 212-220.

Salman, A. K. (2003). Estimating Tourist Demand through Cointegration Analysis: Swedish Data. Current Issues in Tourism, 6, 323-339.

Schwartz, Z., and Cohen, E. (2004). Subjective estimates of occupancy forecast uncertainty by hotel revenue managers. Journal of Travel \& Tourism Marketing, 16, 59-66.

Shan, J., and Wilson, K. (2001). Causality between trade and tourism: Empirical evidence from China. Applied Economics Letters, 8, 279-283.

Smeral, E. (2004). Long-term forecasts for international tourism. Tourism Economics, 10, 145 166.

Smeral, E., and Weber, A. (2000). Forecasting international tourism trends to 2010. Annals of Tourism Research 27, 982-1006.

Smeral, E., and Wüger, M. (2005). Does complexity matter? Methods for improving forecasting accuracy in tourism: The case of Australia. Journal of Travel Research, 44, 100-110.

Song, H. and S. F. Witt (2000). Tourism Demand Modelling and Forecasting: modern econometric approaches. Pergamon: Cambridge.

Song, H., and Turner, L. (2006). Tourism demand forecasting. Dwyer, L., and Forsyth, P. (eds) International Handbook on the Economics of Tourism, Edward Elgar: Cheltenham.

Song, H., and Witt, S. F. (2003). Tourism forecasting: The general-to-specific approach. Journal of Travel Research, 42, 65-74.

Song, H., and Witt, S. F. (2006). Forecasting international tourist flows to Macau. Tourism Management, 27, 214-224.

Song, H., and Wong, K. K. F. (2003). Tourism demand modeling: A time-varying parameter approach. Journal of Travel Research, 42, 57-64.

Song, H., Romilly, P., and Liu, X. (2000). An empirical study of outbound tourism demand in the UK. Applied Economics, 32, 611-624.

Song, H., Witt, S. F., and Jensen, T. C. (2003a). Tourism forecasting: Accuracy of alternative econometric models. International Journal of Forecasting, 19, 123-141.

Song, H., Witt, S. F., and Li, G. (2003b). Modelling and forecasting the demand for Thai tourism. Tourism Economics, 9, 363-387.

Song, H., Wong, K. K. F., and Chon, K. K. S. (2003c). Modelling and forecasting the demand for Hong Kong tourism. International Journal of Hospitality Management, 22, 435-451. 
Syriopoulos, T., and Sinclair, T. (1993). A dynamic model of demand for Mediterranean countries. Applied Economics, 25, 1541-1552.

Tan, A. Y. F., McCahon, C. and Miller, J. (2002). Modelling Tourist Flows to Indonesia and Malaysia. Journal of Travel and Tourism Marketing, 13, 61-82.

Tideswell, C., Mules, T., and Faulkner, B. (2001). An integrative approach to tourism forecasting: A glance in the rearview mirror. Journal of Travel Research, 40, 162-171.

Toshinori, M. (1998). Fundamentals of the New Artificial Intelligence, New York: Springer.

Turner, L. W., and Witt, S. F. (2001a). Factors influencing demand for international tourism: Tourism demand analysis using structural equation modelling, Revisited. Tourism Economics, 7, 21-38.

Turner, L. W., and Witt, S. F. (2001b). Forecasting tourism using univariate and multivariate structural time series models. Tourism Economics, 7, 135-147.

Vanegas, M. Sr., and Croes, R. R. (2000). Evaluation of demand: US tourists to Aruba. Annals of Tourism Research, 27, 946-963.

Veloce, W. (2004). Forecasting inbound Canadian tourism: An evaluation of error corrections model forecasts. Tourism Economics, 10, 263-280.

Vu, C. J. (2006). Effect of demand volume on forecasting accuracy. Tourism Economics, 12, 263 276.

Vu, C. J., and Turner, L. W. (2006). Regional data forecasting accuracy: The case of Thailand. Journal of Travel Research, 45, 186-193.

$\mathrm{Vu}, \mathrm{C}$. J., and Turner, L.W. (2005). Data disaggregation in demand forecasting. Tourism and Hospitality Research, 6, 38-52.

Wang, C. H. (2004). Predicting tourism demand using fuzzy time series and hybrid grey theory. Tourism Management, 25, 367-374.

Webber, A. G. (2001). Exchange rate volatility and cointegration in tourism demand. Journal of Travel Research, 39, 398-405.

White, K. J. (1985). An international travel demand model: US travel to Western Europe. Annals of Tourism Research, 12, 529-545.

Witt, S. F., and Song, H. (2000). Forecasting future tourism flows. Medlik, S and A. Lockwood (eds) Tourism and Hospitality in the $21^{\text {st }}$ Century, Butterworth-Heinemann, Oxford, 106118.

Witt, S. F., and Turner, L. W. (2002). Trends and Forecasts for Inbound Tourism to China. Journal of Travel \& Tourism Marketing, 13, 97-107.

Witt, S. F., and Witt, C. A. (1995). Forecasting tourism demand: A review of empirical research. International Journal of Forecasting, 11, 447-475.

Witt, S. F., Song, H., and Louvieris, P. (2003). Statistical testing in forecasting model selection. Journal of Travel Research, 42, 151-158.

Witt, S. F., Song, H., and Wanhill, S. P. (2004). Forecasting tourism-generated employment: The case of Denmark. Tourism Economics, 10, 167-176.

Wong, K. K. F., Song, H., and Chon, K. S. (2006). Bayesian models for tourism demand forecasting. Tourism Management, 27, 773-780.

Wong, K. K. F., Song, H., Witt, S. F., and Wu, D. C. (2007). Tourism forecasting: To combine or not to combine? Tourism Management, 28, 1068-1078. 